\title{
Gel-Based Luminescent Conductive Materials and Their Applications in Biosensors and Bioelectronics
}

\author{
Jiajin Qi ${ }^{1,2}$, Gongmeiyue $\mathrm{Su}^{1,2}$ and $\mathrm{Zhao} \mathrm{Li}^{1,2, *(D)}$ \\ 1 Institute of Engineering Medicine, Beijing Institute of Technology, Beijing 100081, China; \\ 3220201938@bit.edu.cn (J.Q.); gongmeiyue.su@bit.edu.cn (G.S.) \\ 2 Beijing Key Laboratory for Separation and Analysis in Biomedicine and Pharmaceuticals, \\ Beijing Institute of Technology, Beijing 100081, China \\ * Correspondence: lizhao@bit.edu.cn
}

Citation: Qi, J.; Su, G.; Li, Z.

Gel-Based Luminescent Conductive Materials and Their Applications in Biosensors and Bioelectronics. Materials 2021, 14, 6759. https:// doi.org/10.3390/ma14226759

Academic Editor: Dirk Poelman

Received: 1 October 2021

Accepted: 4 November 2021

Published: 10 November 2021

Publisher's Note: MDPI stays neutral with regard to jurisdictional claims in published maps and institutional affiliations.

Copyright: (c) 2021 by the authors. Licensee MDPI, Basel, Switzerland. This article is an open access article distributed under the terms and conditions of the Creative Commons Attribution (CC BY) license (https:// creativecommons.org/licenses/by/ $4.0 /)$.

\begin{abstract}
The gel is an ideal platform for fabricating materials for bio-related applications due to its good biocompatibility, adjustable mechanical strength, and flexible and diversified functionalization. In recent decades, gel-based luminescent conductive materials that possess additional luminescence and conductivity simultaneously advanced applications in biosensors and bioelectronics. Herein, a comprehensive overview of gel-based luminescent conductive materials is summarized in this review. Gel-based luminescent conductive materials are firstly outlined, highlighting their fabrication methods, network structures, and functions. Then, their applications in biosensors and bioelectronics fields are illustrated. Finally, challenges and future perspectives of this emerging field are discussed with the hope of inspire additional ideas.
\end{abstract}

Keywords: gel-based materials; luminescence; conductivity; applications; biosensors; bioelectronics

\section{Introduction}

With the increasing concern about health by people and large development in science, technology, and medicine, biosensors and bioelectronics became attractive research fields. Biosensors are devices used to detect biological substances through convert biological information into detectable signals [1-3]. Bioelectronics establish the connection between electronic device and the biological body and enable the device to capture and detect physiological signals, so that the biological condition of the biological body can be detected and evaluated [4-7]. Biosensors and bioelectronics experienced tremendous development in the past few decades, mainly due to the application of flexible materials in the fields. Different from traditional rigid biosensors and bioelectronics, flexible ones can establish tighter coupling and better compatibility with soft and dynamically deformed biological surfaces or internal organs, which makes them ideal candidates in monitoring and treatment of diseases, human body movements, and health indexes [8-11]. Currently, flexible biosensors and bioelectronics were widely used in the biomedicine, including biodetection sensors for biomarker detection and wearable bioelectronics devices for monitoring vital signs or capturing epidermal energy [12-15]. As the emerging frontier fields, it brings more requirements to the related materials, including performance and function requirements. On one hand, biosensors and wearable electronic devices are primarily applied in biomedical related areas, which require the materials with excellent biocompatibility and tunable mechanical properties [16-18]. On the other hand, the devices are required to convert the response signal into information that people can easily understand and directly observe.

The gel is an attractive material for research in recent years due to its unique characteristics such as outstanding biocompatibility, adjustable mechanical properties, quasi-liquidsolid behavior, scalability, and void structure $[19,20]$. In addition, functional materials can be facilely introduced into the gel network to endow it with corresponding functions. On the other hand, for the function requirement about signals, luminescent and electrical 
signals are two ideal candidates. The light-emitting process can convert the response into a light signal which owns advantages of high sensitivity and signal-to-noise ratio (SNR), fast response, easy detection, and pollution free [21]. The conductivity is one of the electric signals that can convert the response into resistance or conductivity change and has the superiorities of high selectivity and accuracy, good stability, easy to control, and high-familiarity [22,23].

Introducing luminescence or conduction function into gel matrix can afforded functional gel-based materials with corresponding characteristics. These functional materials were widely applied in numerous areas. For example, luminescent gels and conductive gels, which are widely concerned by people, were extensively used in sensors, bioelectronics, biomedicine, human-computer interaction, and soft robotics [24,25]. However, the singularity of the function in the gels restricts their further applications in many high-tech areas because many of the areas require the materials with multiple functions. Gel-based materials integrating the functions of luminescence and conductivity simultaneously can show both features of luminescence and conduction and in many cases have unexpected characteriastics due to the synergistic effect. The function versatility makes the material closer to the application demands in high-tech areas such as biosensors and bioelectronics. Therefore, the gel-based luminescent conductive material as an emerging advanced functional material has many superior characters and has made great progress in biosensors and bioelectronics recently.

The research of gel-based luminescent conductive materials and bio-applications of them involves multidisciplinary knowledge and technologies. The interdisciplinary research can give birth to new direction and provide opportunities for more advanced applications. Although the field of gel-based luminescent conductive materials was developed rapidly in recent years, the periodical summary of it is lacking. An overview of this field can not only provide researchers a comprehensive understanding about it and motivate new ideas, but also showcase the scientific thought about interdisciplinary research. Therefore, herein a review about recent progress on gel-based conductive luminescent materials and their applications in biosensing and bioelectronics will be provided (Figure 1). Firstly, an overview of gels, luminescent materials, and conductive materials is provided. Then, gel-based luminescent conductive materials, including luminescent conductive gels and luminescent conductive gel composites, are summarized and reviewed. The preparation strategies, network structures, and performances about functions of luminescence and conductivity are highlighted. Subsequently, the application of the gel-based luminescent conductive materials in the areas of biosensing and bioelectronics is explained. Finally, current challenges and future prospects of this field are given, aiming to bring new insights into the development and commercial applications of biosensing and bioelectronic products.

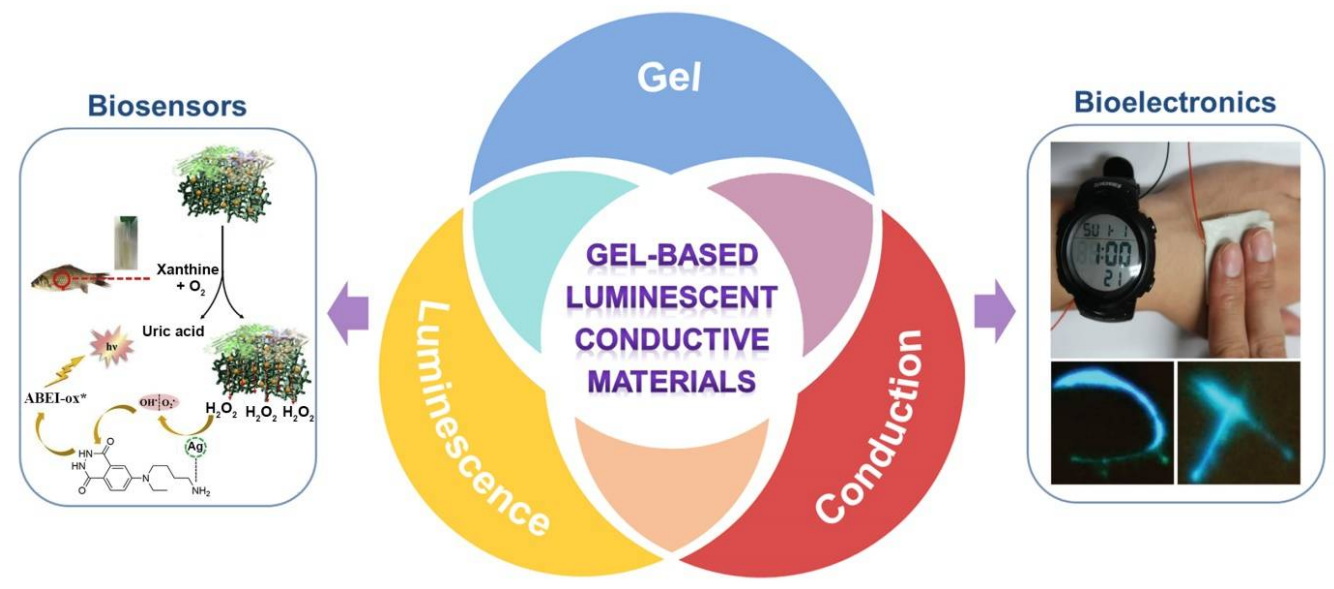

Figure 1. Summary of gel-based luminescent conductive materials and their applications in biosensors and bioelectronics. Figure of application example in biosensors was adapted with permission [26]; copyright 2019, Elsevier Ltd. Figure of application example in bioelectronics was adapted with permission [27]; copyright 2019, Wiley-VCH Verlag GmbH \& Co. KGaA, Weinheim. 


\section{Gels, Luminescent Materials, and Conductive Materials}

\subsection{Gels}

The gel is a three-dimensional (3D) network filled with a dispersion medium in a matrix, and it is considered to be intermediate between liquid and solid. So far, various gels were developed and there are many classification standards to categorize them. For example, according to the dispersion medium inside the gel matrix, it can be classified as hydrogel, organic gel, aerogel, and xerogel. According to the constitution, gels can be divided into the macromolecular gel and supramolecular gel. The main constitution of the former is covalently formed macromolecules, while the major constituent of the latter is low molecular-weight gelators (LMWGs). Moreover, the gel can form through either physical or chemical bonds, indicating that the gels cross-linking by noncovalent physical bonds are physical gels, whereas crosslinking by covalent chemical bonds refers to chemical gels. In addition, gels can also be classified according to their size. The gel in macroscopic size is called macroscopic or bulk gel, and the gel with size in the micron or nanoscale is known as nano-micro gel [28-33].

\subsection{Luminescent Materials}

Luminescence mainly refers to the process of absorbing external energy inside an object at the ground state, reaching to the excited state, and finally, releasing the energy through light emission to get back to the ground state. According to the kind of energy absorbed, luminescence can be divided into photoluminescence (PL), electroluminescence (EL), chemiluminescence (CL), and sonoluminescence (SL). PL is a phenomenon in which an object emits light upon irradiation by ultraviolet light or visible light [34]. EL is the phenomenon of luminescence when an object passes through an electric current or is in an electric field [35]. CL refers to the luminescence phenomenon that accompanies the generation of light in the process of chemical reactions. Electrochemiluminescence (ECL) is one of a representative type of CL. It produces luminescence by applying a certain electrical signal to a chemical system containing chemiluminescent substances by electrodes [36,37]. SL occurs in liquids and refers to a kind of "sonic cavitation" phenomenon in the liquid when the liquid is subjected to strong sound waves. Specifically, bubbles are generated in the liquid, and the bubbles are instantly reduced to a tiny volume. During the process, they will emit flashes and release a large amount of heat [38].

Luminescent materials refer to functional materials that convert various forms of energy absorbed from the outside into light radiation. They usually emit visible light but can also be ultraviolet and infrared light. There are many types of luminescent materials, such as organic luminescent materials, transition metal complexes, luminescent nanomaterials, and zinc sulfide-based materials.

Organic luminescent materials can have luminescent pathways of photoluminescence, electroluminescence, chemiluminescence and electrochemiluminescence, in which PL organic compounds are in the majority. Interestingly, some organic PL materials can only emit light in a dilute solution. Once the concentration of the solution increases to accumulate the molecules, their luminescence will weaken or even disappear entirely. This phenomenon is called aggregation-caused quenching (ACQ) [39]. On the contrary, some organic molecules emit weakly in low-concentration solutions, but their PL is significantly enhanced after aggregation. This phenomenon is called aggregation-induced emission (AIE) [40]. PL materials with these phenomena or behaviors may endow their constructed materials with more diverse functions and stimuli-responsiveness. Currently, organic luminescence materials are widely used and are among the most critical vital materials in various application areas, such as fluorescent coatings, flexible optoelectronic devices, biological probes, information-related areas, and environmental protection. Luminol is one of the most commonly used organic CL materials, which can be oxidized by peroxides under alkaline conditions and emit blue light at the same time [41,42].

Transition metal-organic complexes have the advantages of both inorganic and organic compounds, which drew much attention in the field of luminescence. Iridium (Ir) 
complexes, ruthenium $(\mathrm{Ru})$ complexes, and lanthanide complexes are typical examples of the metal-organic complexes [43-45]. Ir complexes are luminous bodies with good secondand third-order nonlinear optical responses. They have excellent properties, such as high luminescence quantum yield, large Stokes shift, and long luminescence lifetime [46]. Ru complexes are six-coordinate octahedral configuration complexes, a triplet luminophore with a long luminescence lifetime, long emission wavelength, and low cytotoxicity [47]. Lanthanum ion complexes are a kind of critical fluorescent material with unique metalcontrolled photoluminescence behavior due to its particular electronic structure, high intensity, and high purity [48,49].

Fluorescent nanoparticles refer to nanoparticles or nanocrystals with less than $100 \mathrm{~nm}$ diameter that can emit fluorescence [50]. The present fluorescent nanoparticles mainly include quantum dots (QDs), carbon dots (CDs), metal nanoclusters (NCs), and perovskite nanocrystals (PNCs), and fluorescent dye-doped silica nanoparticles (DSNPs).

QDs with unique optical and electrical characteristics are semiconductor particles with nanostructure. Optoelectronic properties of QDs are related to the size, shape, and quantum physics of the particles [51]. CDs are composed of spherical-like carbon nanoparticles below $10 \mathrm{~nm}$ and are a new type of nano-carbon material with fluorescent properties [52,53]. NCs are composed of several to a few hundred atoms. Its size is between atoms and nanoparticles. NCs have different characteristics from metal nanoparticles, such as discrete electronic energy levels, high quantum yields, tunable fluorescence emission and good photostability. [54-58]. PNCs is a unique structure of perovskite, their size is on the order of nanometers, and the quantum effect is significant [59]. DSNPs are composite luminescent nanomaterials in which fluorescent dyes are doped into nano-silica [60].

Zinc sulfide (ZnS) is a vital semiconductor material of group II-VI with good optical and electrical properties, which can be applied in light-emitting diodes, optoelectronic devices, sensors, lasers, and other fields. ZnS alone is difficult to produce the stable and excellent performance of luminescence. Indeed, the performance of $\mathrm{ZnS}$ nanomaterials can be significantly improved through doping modification. The current doping mainly includes rare earth elements, transition metal elements, and other elements, such as zinc sulfide doped copper ( $\mathrm{ZnS}: \mathrm{Cu}$ ) and zinc sulfide doped manganese (ZnS:Mn) [61,62].

\subsection{Conductive Materials}

Conductive materials are the substance that can provide conductivity under the action of an electric field. So far, various conductive materials were developed, mainly including conductive nanomaterials, conductive polymers, ionic conductors, and low-molecular weight organic compounds with the conjugated structure.

Ionic conductors conduct electricity through the directional movement of ions. Ionic conductors cannot complete the conductive task independently, and often need to be used in connection with electronic conductors. Usually, inorganic salt ions are dissolved in the solution or doped into materials containing the solution (such as hydrogel) to prepare the ion conductor. Most of the ions are free in the solution, namely free ions. In some cases, ions have interactions with material matrix. For example, some metal ions can form coordination bonds with gel network chain and act as both physical cross-linking points and conductive species [63,64].

Ionic liquids (ILs) are a special kind of ion conductor, which are liquids composed entirely of ions. It has the characteristics of high conductivity, low vapor pressure, and good stability. In addition, the melting point of ILs is relatively low, usually below $100{ }^{\circ} \mathrm{C}$ [65-67]. Deep eutectic solvents (DES) are composed of two or more clean and safe ingredients (urea, choline chloride, etc.) through hydrogen bond interaction. Deep eutectic solvents usually remain liquid below $100{ }^{\circ} \mathrm{C}$. They have many similarities with ionic liquids but are cheaper and safer than ionic liquids $[68,69]$.

Some low-molecular weight conjugated organic compounds can also exhibit conductivity in supramolecular gels. These compounds can assemble to form fibers through noncovalent interactions such as $\pi-\pi$ stacking, donor-acceptor interaction, hydrogen bond, 
electrostatic interaction, and van der Waals interaction. The fibers can form network through further assemble and intertwine. Electrons can transport through the $\pi$-conjugated fiber chain, which endow the material with conduction [70-72].

Conductive polymers are organic electronically conjugated macromolecules characterized by their ability to conduct electrons. They transport electrons through $\pi$-conjugated chains and "doping" processes involving chemical or electrochemical methods. Polyaniline (PANi), polythiophene, polypyrrole (PPy), and poly(3,4-ethylenedioxythiophene): polystyrene sulfonate (PEDOT:PSS) are typical conductive polymers. PANi, a chemical or electrochemical polymerized monomer aniline substance, are commonly used conductive polymers to construct soft conductive materials. It has the advantages of easy synthesis, antibacterial property, high conductivity, and promotion of cell proliferation and differentiation $[73,74]$.

Conductive nanomaterials are another large group of conductive materials. They are mainly divided into two categories, carbon-based nanomaterials, and metal-based nanoparticles. Carbon-based nanomaterials mainly include graphene, carbon black, carbon fibers (CFs), fullerene, and carbon nanotubes (CNTs). Carbon-based nanomaterials are considered one of the most promising conductive materials due to their unique high conductivity, environmental stability, and low production cost. Among the above-mentioned carbon-based nanomaterials, graphene is a two-dimensional carbon nanomaterial composed of a single layer of carbon atoms with an $\mathrm{sp}^{2}$ hybrid hydrocarbon skeleton, which has superconductivity, high surface area, outstanding thermal conductivity, and excellent mechanical strength. Thus, it is an excellent carbon-based conductive dopant to be widely applied in soft materials for biosensing and bioelectronics [75,76]. Metal-based nanoparticles are nano-scale particles, and their optical properties and electrical conductivity are affected by the size. Metal-based nanomaterials have a high electrical conductivity of bulk metals, and have the properties of nanomaterials (magnetic properties, catalytic properties, and antibacterial properties), making them have potential applications in biomedicine. Au nanoparticles (Au NPs), Au nanoclusters (Au NCs), Ag nanofibers (Ag NFs), and Ag nanowires (Ag NWs) are typical metal-based nanoparticles usually used in soft conductive materials. In particular, Au NPs are critical metal nanoparticles with unique conductive, optical, and magnetic properties, ease synthetic procedure, high stability, and good biocompatibility.

\section{Gel-Based Luminescent Conductive Materials}

The gel is a remarkably flexible material. In recent years, due to the good biocompatibility, flexibility, stretchability, and functionality, it was always at the forefront of developing smart materials. Gel-based luminescent conductive materials are an emerging type of multifunctional flexible materials with both luminescent and conductive properties, which is an ideal choice for wearable electronic devices, sensors, soft robotics, and many other high-tech field applications [77-80]. This section will review gel-based luminescent conductive materials, focusing on their preparation, constitution and network structure, and properties. Two kinds of materials are involved. One is the luminescent conductive gel, which is a gel with both luminescent and conductive properties. The other is gel composite with luminescent and conductive properties, composed of luminous or conductive gel combining with flexible materials such as elastomers.

\subsection{Luminescent Conductive Gels}

Luminescent conductive gels are generally prepared by introducing conductive materials and luminescent materials into the gel matrix. Different synthetic methods were developed to prepare luminescent conductive gels.

Luminescent materials and conductive materials can also be components of the gel network. Ajayaghosh and Sánchez et al. reported that $\mathrm{N}$-annulated perylenedicarboxamide (NPDC) (Figure 2A) self-assembled in toluene to form columnar aggregate fibers. Then, the fibers bound to form an organic gel. Fluorescent property of NPDC endowed the gel with luminescence behavior. The gel can convert between sol and gel under temperature changes, 
and emit light green fluorescence under $360 \mathrm{~nm}$ ultraviolet (UV) light (Figure 2B,C). The emission spectrum of the gel covers the visible spectrum and shows maximum emission intensity at about $546 \mathrm{~nm}$ (Figure 2D). Atomic force microscopy (AFM) imaging revealed the gel is composed of fine thread-like fibers (Figure 2E). NPDC is low-molecular weight conjugated organic compounds, which can form a $\pi$-conjugated chain through $\pi$ - $\pi$ stacking. Electrons are transported through the $\pi$-conjugated chain, making the gel conductive. The electrical conductivity of the gel is good, and its electrical conductivity measured by Four-Probe Conductivity (FPC) is $1.92 \times 10^{-4} \mathrm{~S} \cdot \mathrm{m}^{-1}$ (Figure 2F) [81].
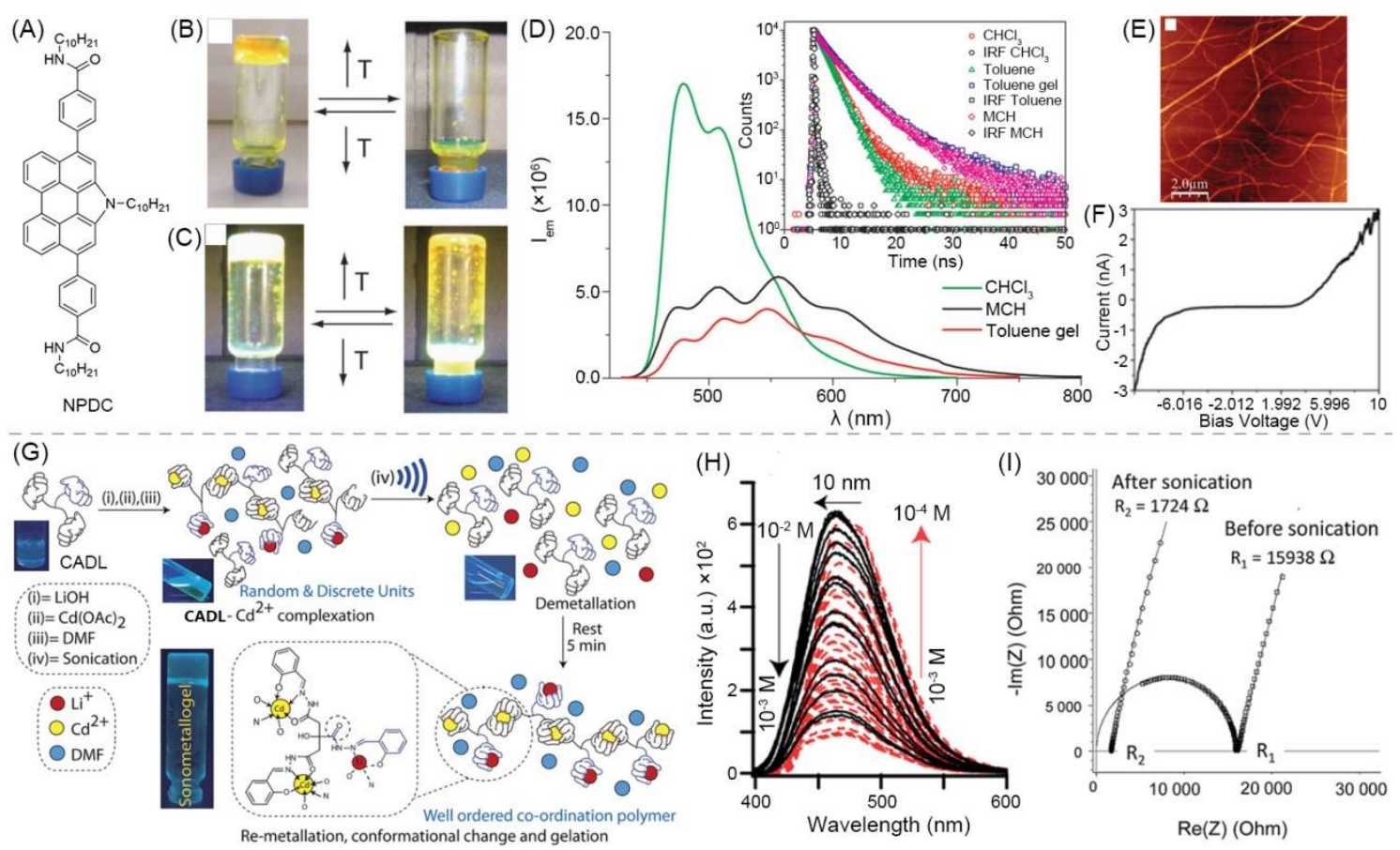

Figure 2. (A) Chemical structure of NPDC. Photographs of gel-to-sol transition of NPSC-based organogel without (B) and with (C) $360 \mathrm{~nm}$ UV illumination. (D) PL spectra of NPDC under different conditions $\left(\lambda_{\mathrm{ex}}=420 \mathrm{~nm}\right)$ with inset showing fluorescence lifetime-decay profiles. (E) AFM image of aggregations of NPDC. (F) CAFM image of toluene gel of NPDC onto HOPG as surface. Adapted with permission [81]; copyright 2013, Royal Society of Chemistry. (G) Schematics of fabrication procedure of sonometallogel from CADL and metal ions along with fluorescent photographs. (H) PL spectra showing dilution of sonometallogel to demonstrate presence of AIE and ACQ phenomena. (I) Experimental Nyquist impedance diagrams before and after sonication. Adapted with permission [82]; copyright 2017, Royal Society of Chemistry.

Introducing metal ions to coassemble with LMWGs can also affords supramolecular luminescent conductive gel. Dubey et al. used a citric acid derived ligand (CADL), $\mathrm{LiOH}$, and $\mathrm{Cd}(\mathrm{OAc})_{2}$ to synthesize a fluorescent metal gel with multistimuli responsiveness through ultrasound induction in $\mathrm{N}, \mathrm{N}$-dimethylformamide (DMF). At the beginning, $\mathrm{Cd}^{2+}$ and CADL complexed without forming a gel. After ultrasonic treatment, the $\mathrm{Cd}^{2+}$ ions were demetalized and recomplexed, eventually leading to gelation (Figure 2G). The gel emits blue light when irradiated by UV light. It emits light with AIE and ACQ phenomena. The fluorescence intensity decreases when the gel is diluted from $10^{-2} \mathrm{M}$ to $10^{-3} \mathrm{M}$, and the fluorescence intensity increases from $10^{-3}$ to $10^{-4} \mathrm{M}$ (Figure $2 \mathrm{H}$ ). The gel conducts electricity through the directional movement of $\mathrm{Li}^{+}$and $\mathrm{Cd}^{2+}$ in the network. The conductivity of the gel itself is poor $\left(4.5 \times 10^{-3} \mathrm{~S} \cdot \mathrm{m}^{-1}\right)$, but it can be effectively increased by about ten times after ultrasonication $\left(4.06 \times 10^{-2} \mathrm{~S} \cdot \mathrm{m}^{-1}\right)$ (Figure 2I). This is because the inside of the gel becomes more organized or orderly after ultrasonication, which increases the $\mathrm{Li}^{+}$ mobility [82].

Table 1 summarized that some typical luminescent conductive gels are composed of self-assembled functional low molecular-weight gelators or low molecular-weight gelators with ions constitute gel matrix. 
The polymer-based gel can be used as a matrix to construct luminescent conductive gels. Li and Shan et al. designed an ECL hydrogel for xanthine detection. Firstly, a conductive polymer hydrogel of polyaniline (PAni) (PAni-ATMP) was prepared from aniline (Ani), amino trimethylene phosphonic acid (ATMP), and $\left(\mathrm{NH}_{4}\right)_{2} \mathrm{~S}_{2} \mathrm{O}_{8}$. Then, the $\mathrm{N}$-(aminobutyl)- $\mathrm{N}$-(ethylisoluminol) functionalized silver nanoparticles (ABEI-Ag) were immobilized on the hydrogel (ABEI-Ag@PAni-ATMP) by ATMP. Finally, the gel was combined with xanthine oxidase (XOD). The electrical conductivity of the gel was provided by PAni. When xanthine acts on the hydrogel with an electric field, $\mathrm{H}_{2} \mathrm{O}_{2}$ is decomposed by electrochemically reacting with $\mathrm{ABEI}-\mathrm{Ag}$, and an ECL signal occurs (Figure $3 \mathrm{~A}$ ). The Nyquist plot was measured with Ani-ATMP and PAni-ATMP modified glassy carbon electrodes (GCE). Compared with the semicircle diameter of Ani-ATMP, the semicircle diameter of PAni-ATMP modified GCE was significantly reduced, indicating that the gel has excellent conductivity (Figure 3B). In the presence of $20 \mu \mathrm{M} \mathrm{H}_{2} \mathrm{O}_{2}$ on ABEI-Ag@PAniATMP gel, a clear ECL signal was observed, and the ECL signal reached about 6000 au., the ECL peak was located at about $0.7 \mathrm{~V}$ (Figure 3C) [26].
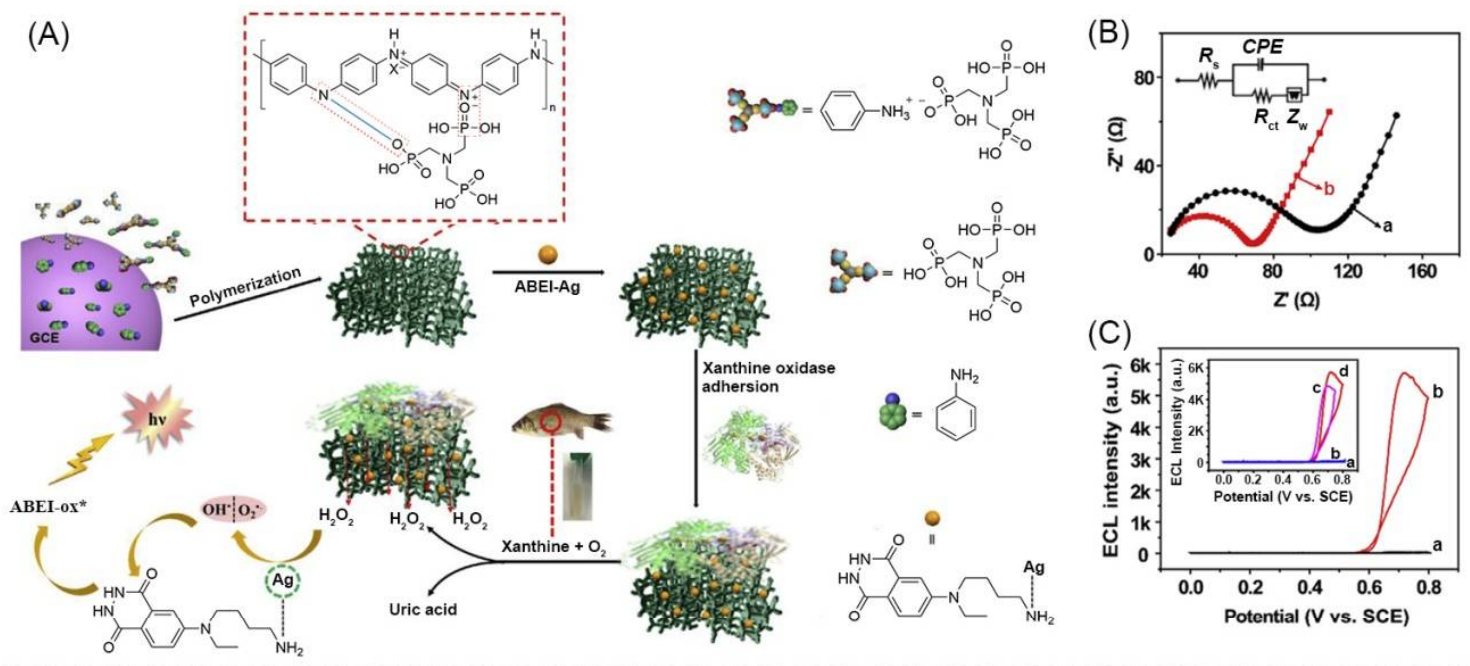

(D)

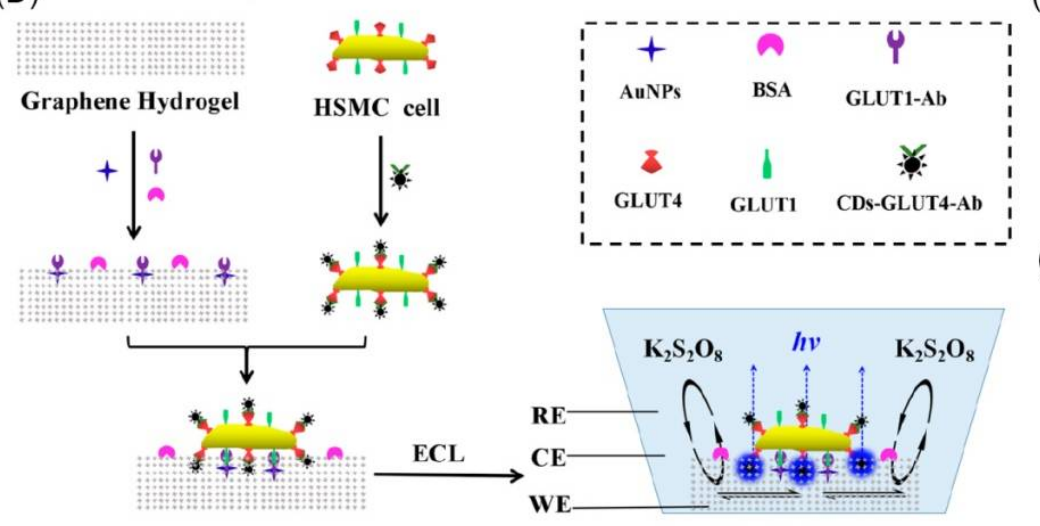

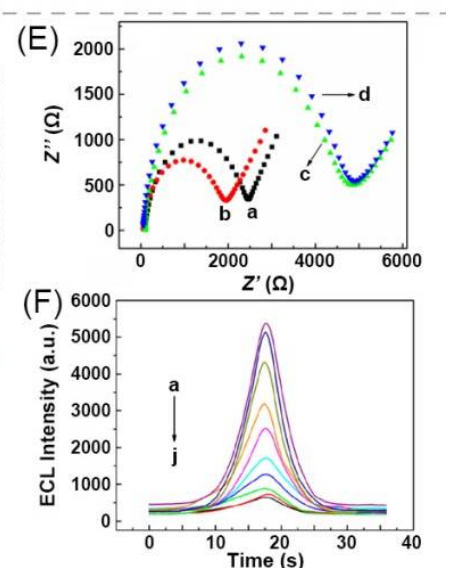

Figure 3. (A) Schematic of preparation process of PAni polymeric hydrogel-based ABEI-Ag@PAni-ATMP ECL biosensor for xanthine. (B) EIS of Ani-ATMP modified GCE (a) and PAni-ATMP modified GCE (b). (C) ECL-potential curve of ABEI-Ag@PAni-ATMP in presence of $20 \mu \mathrm{M} \mathrm{H}_{2} \mathrm{O}_{2}$ with a scan rate of $50 \mathrm{mV} \cdot \mathrm{s}^{-1}$. Adapted with permission [26]; copyright 2019, Elsevier Ltd. (D) Schematic of fabrication process of graphene hydrogel-based ECL cytosensor. (E) EIS spectra of GH (a), GH/AuNPs (b), GH/AuNPs/GLUT1-Ab/BSA (c), and GH/AuNPs/GLUT1-Ab/BSA/cell@CDs-GLUT4-Ab (d). (F) ECL curves obtained with different recombinant GLUT4 concentrations ( 0 to $4.5 \mathrm{ng} \cdot \mathrm{mL}^{-1}$ from a to $\mathrm{j}$ ). Adapted with permission [83]; copyright 2019, American Chemical Society. 
There are also some other typical examples of luminescent conductive gels with a polymer-based network as the matrix. The information about them is also summarized in Table 1.

Carbon-based nanomaterials can also be used as a matrix to construct luminescent conductive gels. Jin and Chen et al. prepared an ECL gel based on graphene hydrogel $(\mathrm{GH})$. The preparation scheme is shown in Figure 3D. Au NPs modified with glucose transporter 1 antibody (GLUT1-Ab) and bovine serum albumin (BSA) were immobilized on GH. Human skeletal muscle cells (HSMC) containing GLUT1 and GLUT4 on the surface are labeled with GLUT4-Ab-functionalized carbon dots (CDs-GLUT4-Ab) by GLUT4. After the labelled cells were fixed on the GH-based electrode, a gel with ECL is prepared (GH/AuNPs/GLUT1-Ab/BSA/cell@CDs-GLUT4-Ab). When an electrochemical reaction occurred, the co-reactant $\mathrm{K}_{2} \mathrm{~S}_{2} \mathrm{O}_{8}$ diffused through the $\mathrm{GH}$ and reacted with the $\mathrm{CD}$ on the bottom surface of the HSMC to generate an ECL signal (Figure 3D). GH/AuNPs/GLUT1$\mathrm{Ab} / \mathrm{BSA} /$ cell@CDs-GLUT4-Ab is conductive (Figure 3E). As the concentration of GLUT4 increased, the ECL peak value continued to decrease (Figure 3F) [83].

In addition, some representative examples, which are some luminescent conductive supramolecular gels constructed from nanomaterials, are summarized in Table 1.

Besides luminescent conductive gels, some photoluminescent supramolecular gels can respond to the electric field. The medium of the gel is liquid crystal, which has certain responsiveness to the electric field. Networks of the gels are formed through the selfassembly of luminescent low-molecular-weight gelators. The liquid crystal can be aligned by applying the electric field and changing the transmittance of the gel. Under the action of an electric field, the optical behavior, such as fluorescence intensity [84], switching of optical transmittance [85], and optical contrast [86], of the luminescent gel can change. 
Table 1. Summary of information of typical luminescent conductive gels involved in this review.

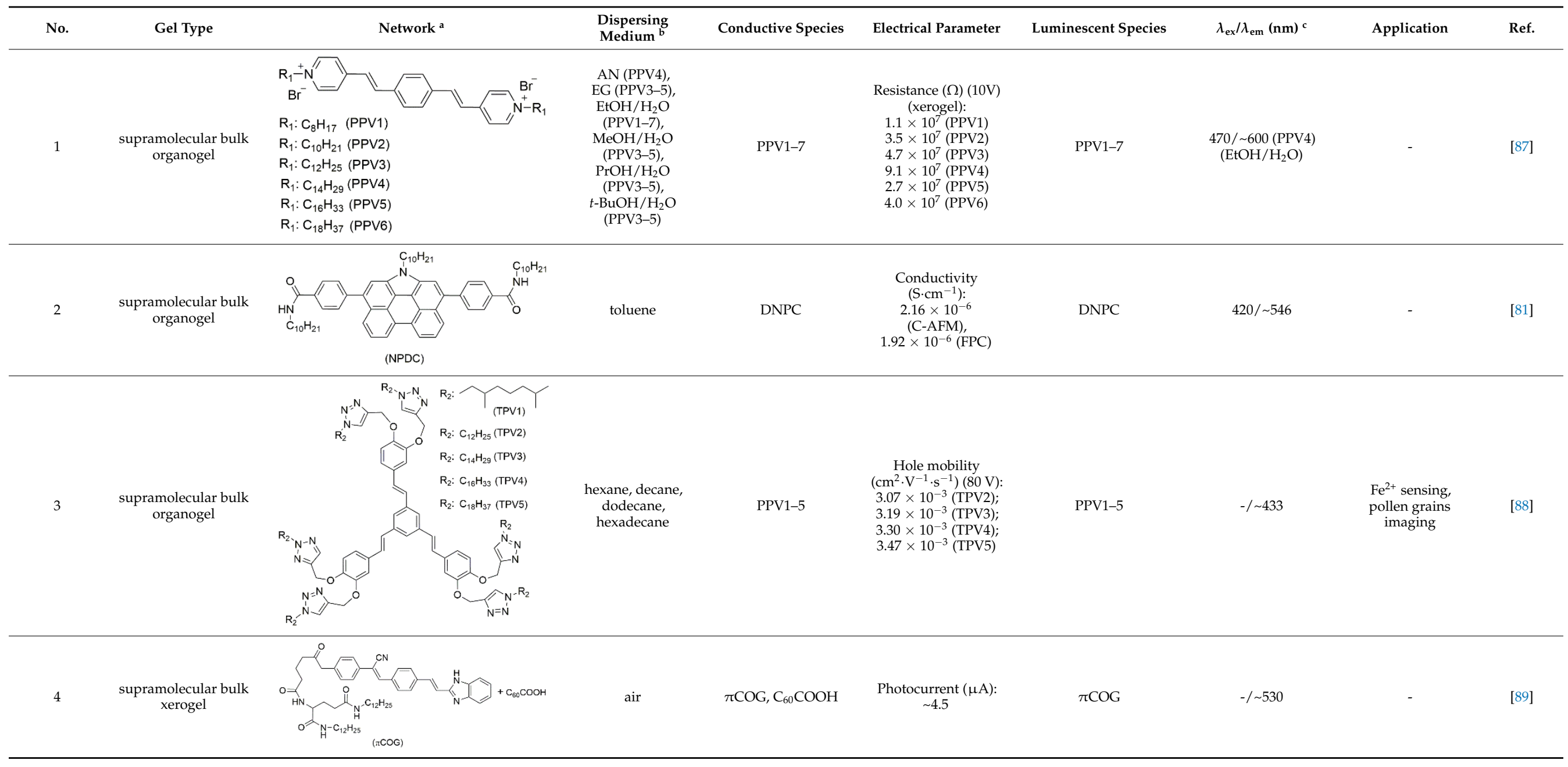


Table 1. Cont

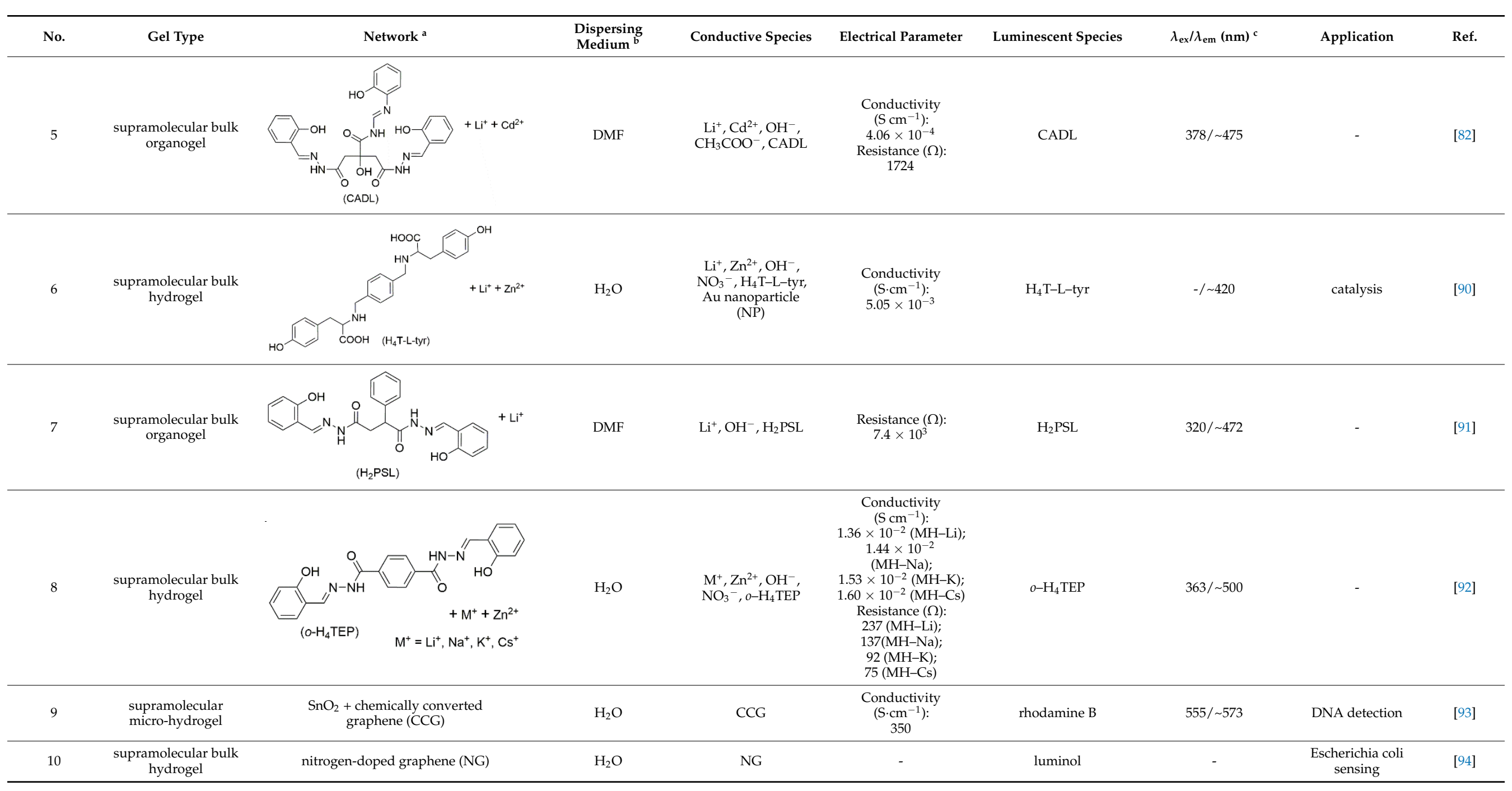


Table 1. Cont.

\begin{tabular}{|c|c|c|c|c|c|c|c|c|c|}
\hline No. & Gel Type & Network $^{a}$ & $\begin{array}{l}\text { Dispersing } \\
\text { Medium }^{\mathrm{b}}\end{array}$ & Conductive Species & Electrical Parameter & Luminescent Species & $\lambda_{\mathrm{ex}} / \lambda_{\mathrm{em}}(\mathrm{nm})^{\mathrm{c}}$ & Application & Ref. \\
\hline 11 & $\begin{array}{l}\text { polymeric bulk } \\
\text { hydrogel }\end{array}$ & polyaniline (PAni) + phytic acid (PA) & $\mathrm{H}_{2} \mathrm{O}$ & PAni, PA & - & $\begin{array}{l}\text { N-(aminobutyl)-N- } \\
\text { (ethylisoluminol) } \\
\text { (ABEI) }\end{array}$ & - & $\begin{array}{c}\text { Live cell } \mathrm{H}_{2} \mathrm{O}_{2} \\
\text { detection }\end{array}$ & [95] \\
\hline 13 & $\begin{array}{c}\text { supramolecular bulk } \\
\text { hydrogel }\end{array}$ & graphene & $\mathrm{H}_{2} \mathrm{O}$ & graphene, AuNP & - & carbon dot (CD) & $410 / \sim 517$ & $\begin{array}{l}\text { cytosensor, } \\
\text { glucose } \\
\text { transporter } 4 \\
\text { expression } \\
\text { evaluation }\end{array}$ & [83] \\
\hline 14 & $\begin{array}{l}\text { polymeric bulk } \\
\text { hydrogel }\end{array}$ & PAni + ATMP & $\mathrm{H}_{2} \mathrm{O}$ & PAni & - & ABEI & - & xanthine detection & [26] \\
\hline 15 & $\begin{array}{l}\text { polymeric bulk } \\
\text { hydrogel }\end{array}$ & $\mathrm{BSA}+\mathrm{Au} / \mathrm{Ag}$ nanocluster $(\mathrm{NC})$ & $\mathrm{H}_{2} \mathrm{O}$ & $\begin{array}{c}\mathrm{Na}^{+}, \mathrm{K}^{+}, \mathrm{PO}_{4}{ }^{3-}, \\
\mathrm{Cl}^{-}, \mathrm{NO}_{3}{ }^{-}\end{array}$ & - & $\mathrm{Au} / \mathrm{Ag} \mathrm{NC}$ & $500 / \sim 620$ & $\begin{array}{c}\text { detection of } \\
\text { glutathione (GSH) }\end{array}$ & [97] \\
\hline 16 & $\begin{array}{c}\text { supramolecular bulk } \\
\text { hydrogel }\end{array}$ & $\mathrm{AuAXP}$ nanocluster $(\mathrm{NC})+\mathrm{Ca}^{2+}$ & $\mathrm{H}_{2} \mathrm{O}$ & $\mathrm{Ca}^{2+}, \mathrm{Cl}^{-}$ & - & AuAXP NC & $\sim 500 \mathrm{~nm} \mathrm{ECL}$ & $\begin{array}{l}\text { detection of } \\
\text { calmodulin }\end{array}$ & [98] \\
\hline 17 & $\begin{array}{c}\text { supramolecular bulk } \\
\text { hydrogel }\end{array}$ & Ag-melamine metal-organic gel (Ag-MOG) & $\mathrm{H}_{2} \mathrm{O}$ & Ag-MOG & - & $\begin{array}{c}\text { Tri(2,2'-bipyridyl) } \\
\text { dichlororuthenium(II) } \\
\left(\mathrm{Ru}(\mathrm{bpy}) 3^{2+}\right) \text {;ichlorotris } \\
(1,10-\text { phenanthroline }) \\
\text { ruthenium (II) } \\
\left(\mathrm{Ru}(\mathrm{phen})_{3}{ }^{2+}\right)\end{array}$ & - & DNA detection & [99] \\
\hline 18 & $\begin{array}{c}\text { supramolecular bulk } \\
\text { hydrogel }\end{array}$ & $\mathrm{Au} N \mathrm{NP}$ & $\mathrm{H}_{2} \mathrm{O}$ & $\begin{array}{c}\text { graphite-like carbon } \\
\text { nitride }\left(\mathrm{g}-\mathrm{C}_{3} \mathrm{~N}_{4}\right) \\
\mathrm{Au} \mathrm{NP}\end{array}$ & - & Au NP & $\sim 465 \mathrm{ECL}$ & $\begin{array}{c}\text { Zika Virus } \\
\text { DNA detection }\end{array}$ & {$[100]$} \\
\hline 19 & $\begin{array}{c}\text { supramolecular bulk } \\
\text { hydrogel }\end{array}$ & $\mathrm{Ag}_{9} \mathrm{NC}$ & $\mathrm{H}_{2} \mathrm{O}$ & $\mathrm{Ag}_{9} \mathrm{NC}$ & $\begin{array}{l}\text { Resistance }(\Omega) \text { : } \\
586\end{array}$ & $\mathrm{Ag}_{9} \mathrm{NC}$ & $234 / \sim 575$ & $\begin{array}{l}\text { methyltransferase } \\
\text { Assay }\end{array}$ & [101] \\
\hline 20 & $\begin{array}{l}\text { supramolecular bulk } \\
\text { hydrogel }\end{array}$ & 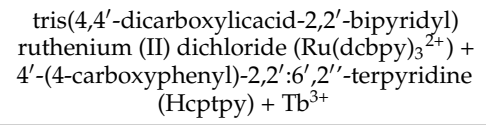 & $\mathrm{H}_{2} \mathrm{O}$ & $\begin{array}{l}\mathrm{Tb}^{3+}, \mathrm{Ru}^{2+}, \\
\mathrm{Cl}^{-}, \mathrm{NO}_{3}-\end{array}$ & - & $\begin{array}{l}\mathrm{Ru}(\mathrm{dcbpy})_{3}{ }^{2+}, \\
\text { Tb complex }\end{array}$ & $\begin{array}{l}-/ \sim 608.4 \\
\sim 679 \mathrm{ECL}\end{array}$ & $\begin{array}{l}\text { epinephrine } \\
\text { detection }\end{array}$ & [102] \\
\hline 21 & $\begin{array}{c}\text { Supramolecular bulk } \\
\text { aerogel }\end{array}$ & $\mathrm{MoS}_{2}$ nanosheet (NS) & air & $\mathrm{MoS}_{2} \mathrm{NS}$ & $\begin{array}{l}\text { Resistance }(\Omega) \text { : } \\
115\end{array}$ & $\begin{array}{c}\text { polydopamine NP } \\
\text { with phenylboronic } \\
\text { acid (PBA) } \\
\text { (PDA-PBA NP) }\end{array}$ & $\begin{array}{c}-/ \sim 457 \\
\text { (PDA-PBA NP); } \\
\sim 600,562,552 \mathrm{ECL} \\
\text { (PDA-PBA NP) }\end{array}$ & $\begin{array}{l}\text { MiRNA-126 } \\
\text { detection }\end{array}$ & [103] \\
\hline 22 & $\begin{array}{l}\text { polymeric bulk } \\
\text { organogel }\end{array}$ & $\begin{array}{c}\text { poly(ethyl } \\
\text { acrylate- } r \text {-styrene- } r \text {-divinylbenzene) } \\
\text { (PEA-r-PS-r-PDVB) }\end{array}$ & $\begin{array}{l}\text { 1-ethyl-3- } \\
\text { methylimidazolium } \\
\text { bis(trifluoromethy } \\
\text { lsulfonyl) imide } \\
\text { ([EMI][TFSI]) }\end{array}$ & [EMI][TFSI] & $\begin{array}{l}\text { Resistance }(\Omega) \text { : } \\
77,520\end{array}$ & $\mathrm{Ru}(\mathrm{bpy})_{3}\left(\mathrm{PF}_{6}\right)_{2}$ & $\sim 612 \mathrm{ECL}$ & wearable ionoskin & [104] \\
\hline
\end{tabular}


Table 1. Cont.

\begin{tabular}{|c|c|c|c|c|c|c|c|c|c|}
\hline No. & Gel Type & Network $^{a}$ & $\begin{array}{l}\text { Dispersing } \\
\text { Medium }^{\mathrm{b}}\end{array}$ & Conductive Species & Electrical Parameter & Luminescent Species & $\lambda_{\mathrm{ex}} / \lambda_{\mathrm{em}}(\mathrm{nm})^{\mathrm{c}}$ & Application & Ref. \\
\hline 23 & $\begin{array}{c}\text { polymeric bulk } \\
\text { organogel }\end{array}$ & $\begin{array}{c}\text { poly(vinylidene } \\
\text { fluoride-co-hexafluoropropylene) } \\
(\mathrm{P}(\mathrm{VDF}-c 0 \text {-HFP) })\end{array}$ & $\begin{array}{l}\text { 1-alkyl-3- } \\
\text { methylimidazolium } \\
\text { bis(trifluoromethy } \\
\text { lsulfonyl)imide } \\
\text { ([AMI][TFSI] } \\
\text { including } \\
\text { [EMI[TFSI], } \\
\text { [BMI][TFSI], } \\
\text { [HMI][TFSI], and } \\
\text { [DMI][TFSI]) }\end{array}$ & [AMI][TFSI] & $\begin{array}{c}\text { Conductivity } \\
\left(\text { S.cm }{ }^{-1}\right): \\
2.5 \times 10^{-3} \\
\text { ([EMI][TFSI]); } \\
1.5 \times 10^{-3} \\
\text { ([BMI][TFSI]); } \\
0.60 \times 10^{-3} \text { ) } \\
\text { ([HMI][TFSI]); } \\
0.28 \times 10^{-3} \\
\text { ([DMI][TFSI]) } \\
\text { Resistance }(\Omega): \\
226 \text { ([EMI][TFSI]) } \\
381 \text { ([BMI][TFI] } \\
939 \text { ([HMI][TFSI]) } \\
2018 \text { ([DMI][TFSI]) }\end{array}$ & 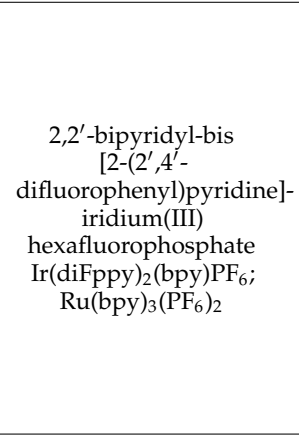 & $\begin{array}{l}\text { green ECL; } \\
\text { red ECL }\end{array}$ & display material & [105] \\
\hline 24 & $\begin{array}{l}\text { polymeric bulk } \\
\text { organogel }\end{array}$ & poly(4-vinyl pyridine) (P4VP) & pyridine & P4VP & $\begin{array}{l}\text { Resistance }(\mathrm{M} \Omega) \\
9-10 \text { (after } \\
385 \mathrm{~nm} \text { radiation) }\end{array}$ & P4VP & $280 / \sim 364,440$ & - & [106] \\
\hline 25 & $\begin{array}{l}\text { polymeric bulk } \\
\text { xerogel }\end{array}$ & $\begin{array}{c}\text { poly(N-[5-(8- } \\
\text { hydroxyquinoline)methyl]aniline) (PNQA) } \\
+\mathrm{V}_{2} \mathrm{O}_{5}\end{array}$ & air & PNQA & $\begin{array}{c}\text { Conductivity } \\
\text { (S.cm } \mathrm{cm}^{-1} \text { ) } \\
\text { (after aging): } \\
3.1 \times 10^{-3}\end{array}$ & PNQA & $373 / \sim 471$ & - & [107] \\
\hline 27 & $\begin{array}{l}\text { polymeric bulk } \\
\text { organogel }\end{array}$ & $\begin{array}{c}\text { poly }(\mathrm{N} \text {-isopropylacrylamide-co- } \mathrm{N} \text { - } \\
\text { vinylcarbazole) } \\
\text { (P(NVC-co-NIPA) })\end{array}$ & dioxane & $\mathrm{P}(\mathrm{NVC}-c o-\mathrm{NIPA})$ & $\begin{array}{c}\text { Conductivity } \\
\left(\mathrm{S} \cdot \mathrm{cm}^{-1}\right) \\
\text { (treated by CAN): } \\
0.017 \text { (S1); } 0.19 \text { (S2); } \\
0.20 \text { (S3); } 0.22 \text { (S); } \\
0.25 \text { (S5); } 0.43 \text { (S) }\end{array}$ & $\mathrm{P}(\mathrm{NVC}-c o-\mathrm{NIPA})$ & $\begin{array}{c}300 /-(\mathrm{S} 1) ; 300 / \sim 373 \\
\text { (S2); 300/ 373 (S3); } \\
300 / 380,410 \text { (S4); } \\
300 / 380,410 \text { (S5); } \\
300 / \sim 420 \text { (S6) }\end{array}$ & - & [109] \\
\hline 28 & $\begin{array}{l}\text { polymeric bulk } \\
\text { hydrogel }\end{array}$ & $\begin{array}{l}\text { La-cholate/poly(acrylamimde) } \\
\text { double network }\end{array}$ & $\mathrm{H}_{2} \mathrm{O}$ & $\begin{array}{c}\mathrm{La}^{3+}, \mathrm{Na}^{+} \\
\mathrm{CH}_{3} \mathrm{COO}^{-}, \mathrm{Cl}^{-}\end{array}$ & $\begin{array}{l}\text { Conductivity } \\
\left(\mathrm{S} \cdot \mathrm{cm}^{-1}\right) \text { : } \\
3 \times 10^{-3}\end{array}$ & La complex & $-/ \sim 430$ & strain sensor & [110] \\
\hline 29 & $\begin{array}{l}\text { polymeric bulk } \\
\text { organogel }\end{array}$ & poly(MMA-HEMA) & $\begin{array}{l}\text { PC- } \gamma \text {-GBL } \\
\text { mixture }\end{array}$ & $\mathrm{TBABF}_{4}$ & - & $\begin{array}{l}\text { TPETPAOMe } \\
\text { BTOTPAOMe }\end{array}$ & $-/ \sim 505 ;-/ \sim 551$ & $\begin{array}{l}\text { electrofluorechromic } \\
\text { devices }\end{array}$ & [111] \\
\hline
\end{tabular}

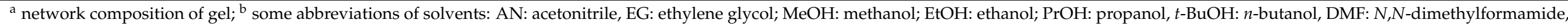

PC: propylene carbonate, $\gamma$-GBL: $\gamma$-butyrolactone; ${ }^{c} \lambda_{\text {ex }}$ : excitation wavelength (for fluorescence), $\lambda_{\mathrm{em}}$ : emission wavelength at maximum intensity of main band (for fluorescence). 


\subsection{Luminescent Conductive Gel Composites}

The luminescent conductive gel composite is a material composed of multiple layers of materials with the participation of gel. It is mainly composed of a conductive layer and a luminescent layer [99,112-115]. Park et al. combined methylammonium lead bromide perovskite nanocrystals ( $\mathrm{MAPbBr}_{3} \mathrm{PNCs}$ ) with aromatic interaction-induced nonpolar organogels (AINOs) through physical or chemical interactions to prepare luminescent green nanocomposite gels (PNC@AINOs). Among them, the one that bound $\mathrm{MAPbBr}_{3} \mathrm{PNCs}_{\text {to }}$ AINOs through physical interaction is M-PNC@AINOs, and the one that bound chemically is V-PNC@AINOs. PNC@AINO gel can emit bright green light under UV light (Figure 4A) originating from PNCs. V-PNC@AINO was used to fabricate a gel composite which was mainly composed of three layers. The first layer was a $\mathrm{LiCl}$ containing polyacrylamide (PAAm) hydrogel. The second layer was an EL elastomeric layer composed of $\mathrm{ZnS}: \mathrm{Cu}-$ $\mathrm{BaTiO}_{3}$ and Ecoflex. The above two layer constituted a stretchable alternating current (AC) electroluminescence (ACEL) layer. The third layer was the V-PNC@AINO color conversion layer (Figure 4B). The ACEL layer can emit bright sky-blue light under the action of an AC electric field. When an AC electric field is applied to the device, the blue light emitted by the ACEL layer excites V-PNC@AINO to emit bright green light through photoluminescence (Figure 4C). The composite device has very little loss of brightness during the color conversion process. Regardless of the applied electric field, the color conversion efficiency remains around 97\% (Figure 4D) [116].

(A) Lead halide perovskite nanocrystals (PNCs)

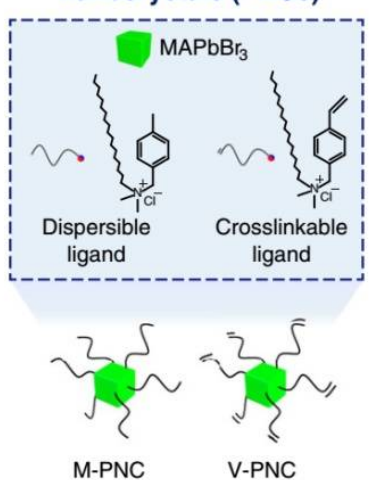

(B)

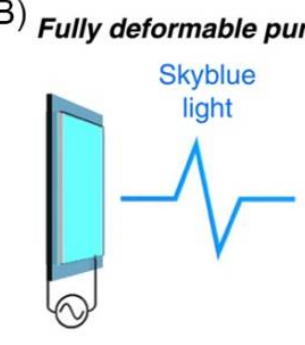

ACEL layer

PAAm hydrogel conductor ZnS:Cu-BaTiO 3 @ Ecoflex
Aromatic interaction-induced nonpolar organogels (AINOs)
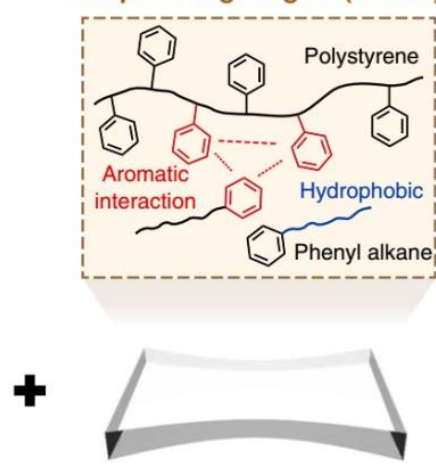

.

(C)

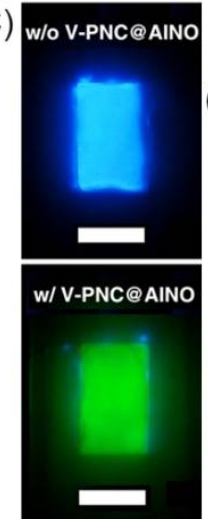

PNC-AINO nanocomposites (PNC@AINOs)

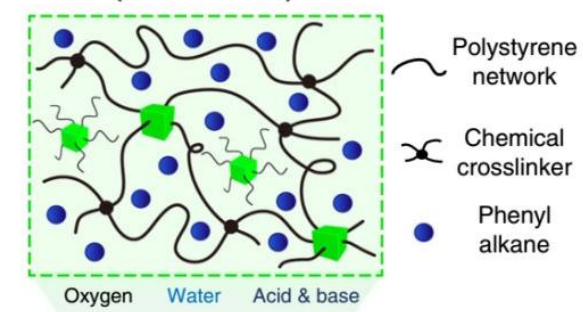

Acid \& base

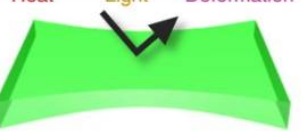

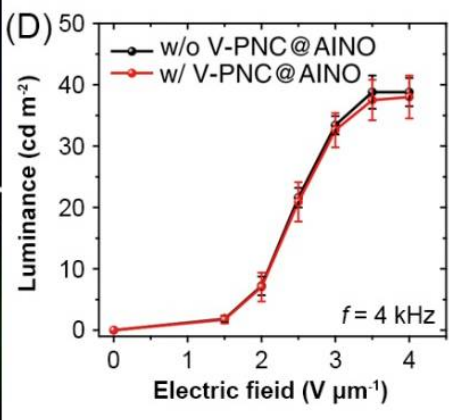

Figure 4. (A) Schematic of structure of green luminescent perovskite nanocomposite gel. (B) Schematic of design of the organogel/Ecoflex/organogel composite-based light-emitting device. (C) Photographs of emission color from ACEL layer without (upper) and with V-PNC@AINO layer (lower). Scale bar =1 cm. (D) Applied AC electric field dependence of Luminance of devices without and with V-PNC@AINO layer. Adapted under terms of Creative Commons Attribution 4.0 International License (CC BY 4.0) (https: / / creativecommons.org/licenses/by /4.0/, accessed on 3 September 2021) [116]; copyright 2020, authors, published by Springer Nature. 
For another example, Fan and Zhi et al. reported a self-healable electroluminescence gel composite device with a sandwich structure. The top and bottom layers are composed of self-healable conductive polyacrylic acid hydrogel, and the middle layer is composed of self-healable phosphor polyurethane. The device emitted blue light after being energized. Because of the self-healing property, the luminescence performance of the devices can be recovered with high healing efficiency. [117]. Yuan et al. reported an electroluminescence gel composite device with the same sandwich structure. $\mathrm{LiCl} /$ agar/polyacrylamide double network hydrogel gel was used as the top and bottom electrodes. The electroluminescent emissive middle layer was composed of polydimethylsiloxane (PDMS) and $\mathrm{ZnS}: \mathrm{Cu}$. The device emits blue light when it is energized. The device made of the ion hydrogel as the conductive layer could obtain better luminous brightness than the indium tin oxide (ITO) as the conductive layer [118].

Typical examples of some luminescent conductive gel composites constructed by combining gel with other materials are summarized in Table 2. 
Table 2. Summary of information of typical luminescent conductive gel composites involved in this review.

\begin{tabular}{|c|c|c|c|c|c|c|c|c|c|}
\hline No. & Layer I & Layer II & Layer III & $\begin{array}{l}\text { Conductive } \\
\text { Species }\end{array}$ & Electrical Parameter & $\begin{array}{l}\text { Luminescent } \\
\text { Species }\end{array}$ & $\begin{array}{c}\text { Luminescent } \\
\text { Parameter }\end{array}$ & Application & Ref. \\
\hline 1 & $\begin{array}{l}\text { polystyrene organic gel + } \\
\text { MAPbBrs PNC } \\
\text { (luminescent layer) }\end{array}$ & 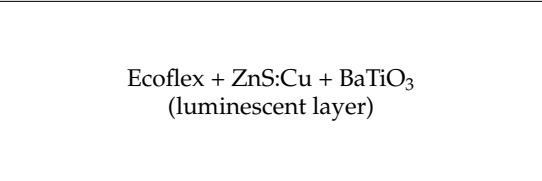 & $\begin{array}{l}\text { PAAm hydrogel }+\mathrm{LiCl} \\
\text { (ionic conductive layer) }\end{array}$ & $\mathrm{Li}^{+}, \mathrm{Cl}^{-}$ & - & 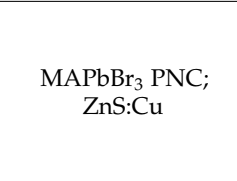 & $\begin{array}{c}\lambda_{\text {ex(PLL }} / \lambda_{\text {em(PL) }}: \\
365 / \sim 555 \\
\text { (V-PNC@AINO); } \\
\text { EL color: } \\
\text { blue } \\
\text { (ZnS:Cu-based layer) }\end{array}$ & soft EL devices & [116] \\
\hline 2 & $\begin{array}{l}\text { PAA hydrogel }+\mathrm{NaCl} \\
\text { (ionic conductive layer) }\end{array}$ & $\begin{array}{c}\text { polyurethane }+ \text { ZnS particle }+ \text { boron } \\
\text { nitride nanosheet } \\
\text { (luminescent layer) }\end{array}$ & $\begin{array}{l}\text { PAA hydrogel }+\mathrm{NaCl} \\
\text { (ionic conductive layer) }\end{array}$ & $\mathrm{Na}^{+}, \mathrm{Cl}^{-}$ & $\begin{array}{l}\text { Conductivity } \\
\left(\mathrm{S} \cdot \mathrm{cm}^{-1}\right): \\
2 \times 10^{-3}\end{array}$ & ZnS particle & $\begin{array}{c}\lambda_{\mathrm{em}(\mathrm{EL})}: \\
\sim 450 ; \sim 500 ; \sim 588\end{array}$ & $\begin{array}{l}\text { light-emitting } \\
\text { device }\end{array}$ & [117] \\
\hline 4 & $\begin{array}{l}\text { agarose-polyacrylamide } \\
\text { (PAAm) hydrogel + LiCl } \\
\text { (ionic conductive layer) }\end{array}$ & $\begin{array}{l}\text { polydimethylsiloxane (PDMS) } \\
\text { elastomer }+\mathrm{ZnS}: \mathrm{Cu} \\
\text { (luminescent layer) }\end{array}$ & $\begin{array}{c}\text { agarose- } \\
\text { polyacrylamide } \\
\text { hydrogel + LiCl } \\
\text { (ionic conductive layer) }\end{array}$ & $\mathrm{Li}^{+}, \mathrm{Cl}^{-}$ & $\begin{array}{l}\text { Resistance }(\Omega) \text { : } \\
\sim 20,000\end{array}$ & $\mathrm{ZnS}: \mathrm{Cu}$ & $\begin{array}{l}\text { EL color: } \\
\text { blue }\end{array}$ & $\begin{array}{l}\text { wearable sensor; } \\
\text { flexible } \\
\text { EL device }\end{array}$ & [118] \\
\hline 5 & $\begin{array}{l}\text { PAAm hydrogel }+\mathrm{LiCl} \\
\text { (ionic conductive } \\
\text { fiber core) }\end{array}$ & $\begin{array}{l}\text { PSPI elastomer }+ \text { ZnS; } \\
\text { PSPI elastomer + CdTe } / \text { ZnS QD } \\
\text { (luminescent sheath) }\end{array}$ & - & $\mathrm{Li}^{+}, \mathrm{Cl}^{-}$ & $\begin{array}{l}\text { Conductivity } \\
\left(\mathrm{S} \cdot \mathrm{cm}^{-1}\right): \\
0.16\end{array}$ & $\mathrm{ZnS} ; \mathrm{CdTe} / \mathrm{ZnS} \mathrm{QD}$ & $\begin{array}{c}\text { EL color: } \\
\text { blue } \\
\text { (ZnS-based sheath); } \\
\text { PL color: } \\
\text { pink } \\
\text { (QD-based sheath) }\end{array}$ & $\begin{array}{c}\text { wearable } \\
\text { motion sensor }\end{array}$ & [119] \\
\hline 7 & $\begin{array}{l}\text { single-walled carbon } \\
\text { nanotube (SWNT) } \\
\text { (conductive fiber core) }\end{array}$ & $\begin{array}{l}\text { supramolecular organic gel of } \\
\text { pyrene-based LMWG } \\
\text { (luminescent middle layer) } \\
\text { (pyrene-based LMWG) }\end{array}$ & silica wall & SWNT & - & $\begin{array}{l}\text { pyrene-based } \\
\text { LMWG }\end{array}$ & $\begin{array}{l}\lambda_{\mathrm{ex}(\mathrm{PL} L} / \lambda_{\mathrm{em}(\mathrm{PL})}: \\
-/ \sim 370,390\end{array}$ & - & [121] \\
\hline
\end{tabular}




\section{Applications in Biosensors and Bioelectronics}

Gel-based luminescent conductive materials are a combination of conductive materials, luminescent materials, and gels. They were widely applied in biology-related areas. In this section, the applications in the areas of biosensors and bioelectronics are reviewed.

\subsection{Biosensors}

A biosensor refers to a device that can convert the concentration information of biological substances into signals such as light and electricity. The development of highsensitivity, fast response, convenient manipulation, and low-cost biosensors is important for modern biomedicine. Luminescent conductive gels with features of gels, luminescent and conductive materials are suitable platforms for biosensor development. Particularly, luminescent conductive gels with ECL are widely used as biosensors to detect biomolecules, cells, and microorganisms.

Guo et al. reported a hydrogel biosensor that can be used to detect glutathione (GSH). The hydrogel comprises BSA and $\mathrm{Au} / \mathrm{Ag}$ alloy nanoclusters (Au/Ag NCs). The sensing system detects GSH through the decrease of ECL intensity in the presence of triethylamine (TEA). This mechanism is due to the reaction between GSH and TEA ${ }^{\bullet+}$ radicals produced from electro oxidation of TEA, which inhibits the reaction between TEA ${ }^{\bullet+}$ radicals and $\mathrm{Au} / \mathrm{Ag} \mathrm{NCs}$, leading to the quenching of ECL (Figure 5A). The ECL intensity of the sensor decreases as the GSH concentration increases. When the GSH concentration is between 20 and $200 \times 10^{-6} \mathrm{M}$, the $\triangle \mathrm{ECL}$ signal $\left(\triangle \mathrm{ECL}=I_{0}-I\right)$ has a linear relationship with the GSH concentration, and the correlation coefficient is 0.982 . The detection limit is $8.7 \times 10^{-6} \mathrm{M}$ (Figure 5B). In addition to detecting GSH, the sensing system also has anti-biofouling and self-healing properties. These characteristics make it suitable for long-term biosensing applications [97]. Wang et al. reported a hydrogel biosensor that can be used to detect calmodulin (CaM). The gel network was formed by connecting Au AXP and $\mathrm{Ca}^{2+}$. The gel has both AIE and aggregation-induced electrochemiluminescence (AIECL) behaviors, and its AIECL signal is 10-times that of AIE (Figure 5C). CaM can specifically bind to the $\mathrm{Ca}^{2+}$ inside the gel to effectively regulate AIECL dynamics, and the ECL signal decreases with the increment of CaM concentration (Figure 5D). Within $0.3-50 \mu \mathrm{g} \cdot \mathrm{mL}^{-1}$, the ECL intensity of the biosensor has a linear relationship with the CaM concentration. The detection limit of the sensor is $0.1 \mu \mathrm{g} \cdot \mathrm{mL}^{-1}$ (Figure 5E) [98].

Ding and Luo et al. reported the construction of an ECL hydrogel cell sensor for detecting cancer cells. PAni-based conductive polymer hydrogel (CPH) was modified with aptamer-tagged Au NPs and was deposited on ITO electrodes. CdTe QDs tagged with the aptamer (CdTe-Apt 2) of cancer cells were used to label cancer cells. The aptamer part facilitated the capture of the cancer cells by the hydrogel electrode surface and the QD part acted as the detection signals. Luminol as another luminogen embedded in $\mathrm{CPH}$ was used as internal standards. The electrochemiluminescence of the formed ratiometric sensor system has double peaks, one is the signal of CdTe-Apt 2 on cancer cells and the other is the luminol signal as the internal standard (Figure 6A) to quantify cancer cells by comparing the sensitivity difference of the bimodal ECL signals with that of target analytes. The ECL intensity of CdTe QDs increases with the increment of cell concentration from 100-6500 cells $\mathrm{mL}^{-1}$, while the ECL intensity of luminol keeps unchanged (Figure 6C). The ratio of $\triangle \mathrm{ECL}_{\mathrm{CdTe}}$ and $\triangle \mathrm{ECL}_{\text {luminol }}$ has a linear relationship with the concentration of target cells in the cell concentration range. The detection limit of the sensor is 80 cells mL $\mathrm{mL}^{-1}$ (Figure 6D) [96]. 

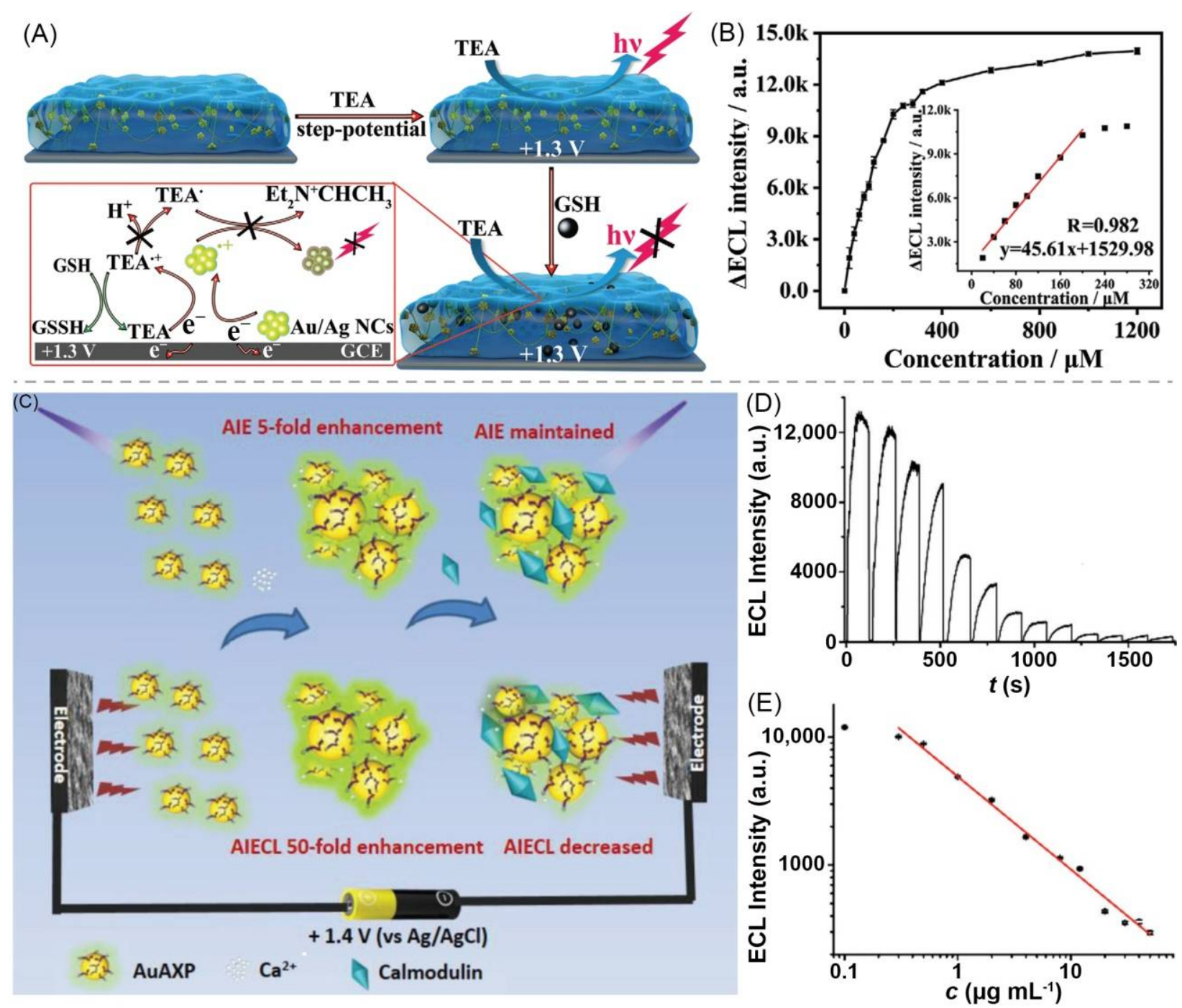

Figure 5. (A) Schematic of mechanism of GSH sensing by Au/Ag NCs@BSA hydrogel. (B) Calibration plot about $\triangle \mathrm{ECL}$ intensity as a function of GSH concentration with inset being linear relationship between $\triangle \mathrm{ECL}$ intensity and GSH concentration. Adapted with permission [97]; copyright 2020, Wiley-VCH Verlag GmbH \& Co. KGaA, Weinheim. (C) Schematic of ECL calmodulin sensor based on bivalent cations-NCs hydrogel. (D) Relationship between ECL intensity and CaM concentration. (0-50 $\mathrm{g} \mathrm{mL}^{-1}$ from left to right) (E) ECL intensity as a function of CaM concentration. Adapted with permission [98]; copyright 2019, Wiley-VCH Verlag GmbH \& Co. KGaA, Weinheim.

For the microorganism sensing, Wang et al. reported an ECL Escherichia coli (E. coli) aptasensor which was prepared by luminol, $\mathrm{AgBr}$ NPs, 3D nitrogen-doped GH (3DNGH), and amine-functionalized E. coli aptamer $\left(\mathrm{NH}_{2}\right.$-aptamer) (Figure $\left.7 \mathrm{~A}\right)$. This sensor can respond E. coli by decreasing the ECL intensity. As the concentration of E. coli increases, the ECL intensity gradually decreases (Figure 7B). The sensor has good performance with the linear sensing range of $0.5-500 \mathrm{cfu} \cdot \mathrm{mL}^{-1}$ and the detection limit of $0.17 \mathrm{cfu} \cdot \mathrm{mL}^{-1}$ (Figure 7C) [94]. 

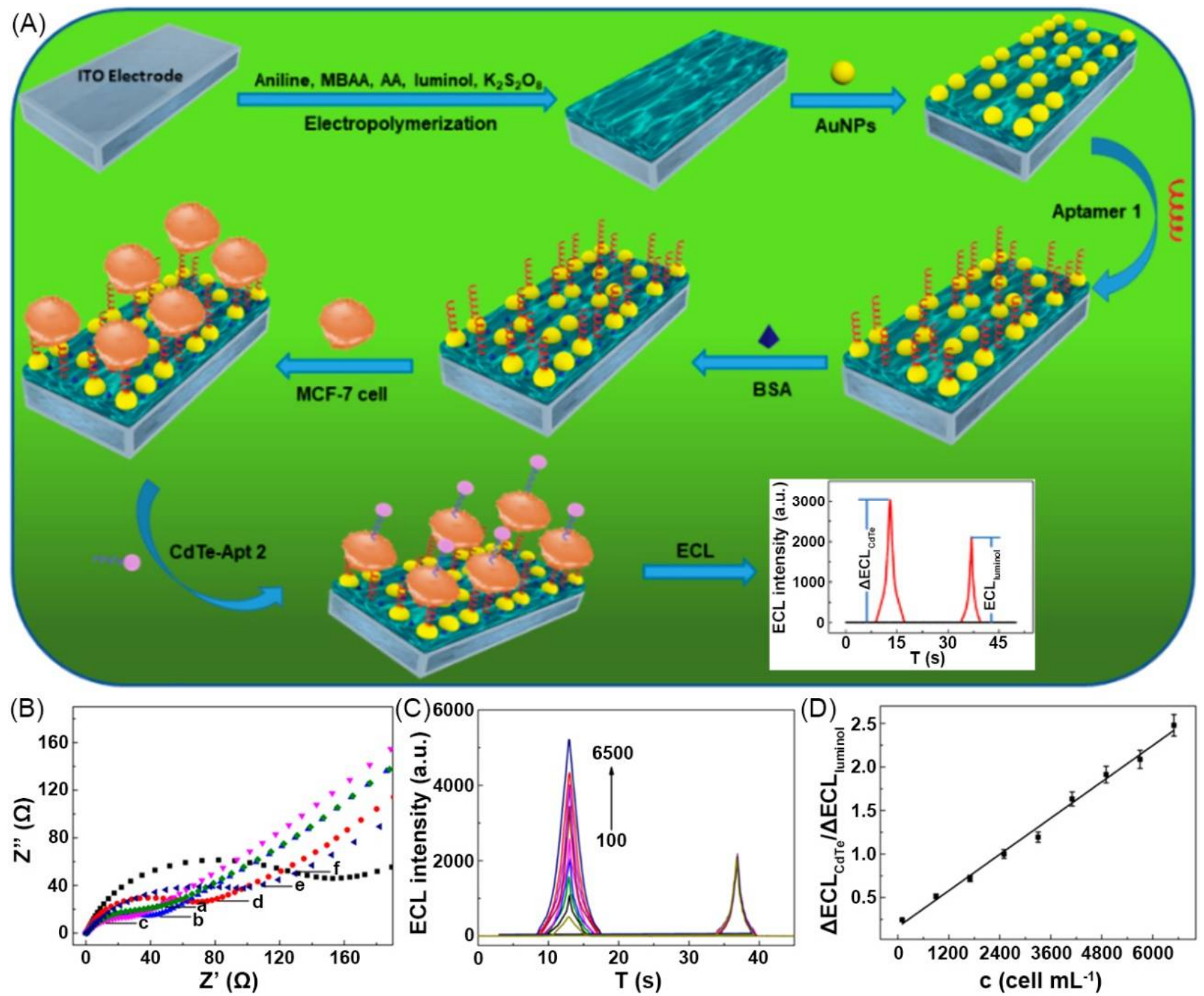

Figure 6. (A) Schematic of ratiometric ECL cytosensor working principle. (B) EIS characterization of sensing interfaces in 0.1 PBS (pH 7.4) with $0.1 \mathrm{KCl}$ and $5.0 \mathrm{mM}\left[\mathrm{Fe}(\mathrm{CN})_{6}\right]^{3-/ 4-}$. (C) Time dependence of ECL intensity of CdTe nanoprobes with different MCF-7 cell concentrations (100-6500 cells $\left.\cdot \mathrm{mL}^{-1}\right)$. (D) Calibration $\Delta \mathrm{ECL}_{\mathrm{CdTe}} / \Delta \mathrm{ECL}_{\text {luminol }}-$ cell concentration curve. Adapted with permission [96]; copyright 2019, American Chemical Society.

\subsection{Bioelectronics}

In recent years, bioelectronics has gradually changed human-computer interaction, such as wearable electronic devices, implantable electronic devices, and human motion detection systems. Flexible bioelectronics can accurately respond to various stimuli in the environment in real-time and output in the form of electrical signals. Moreover, it plays a critical role in intelligent sports, software robots, biomedical monitoring, and diagnosis confirmation. Gel-based luminescent conductive materials combine the flexibility and good biocompatibility of gels with conductivity and fluorescence that can respond to environmental stimuli, making them have excellent application prospects in the field of flexible bioelectronics. 

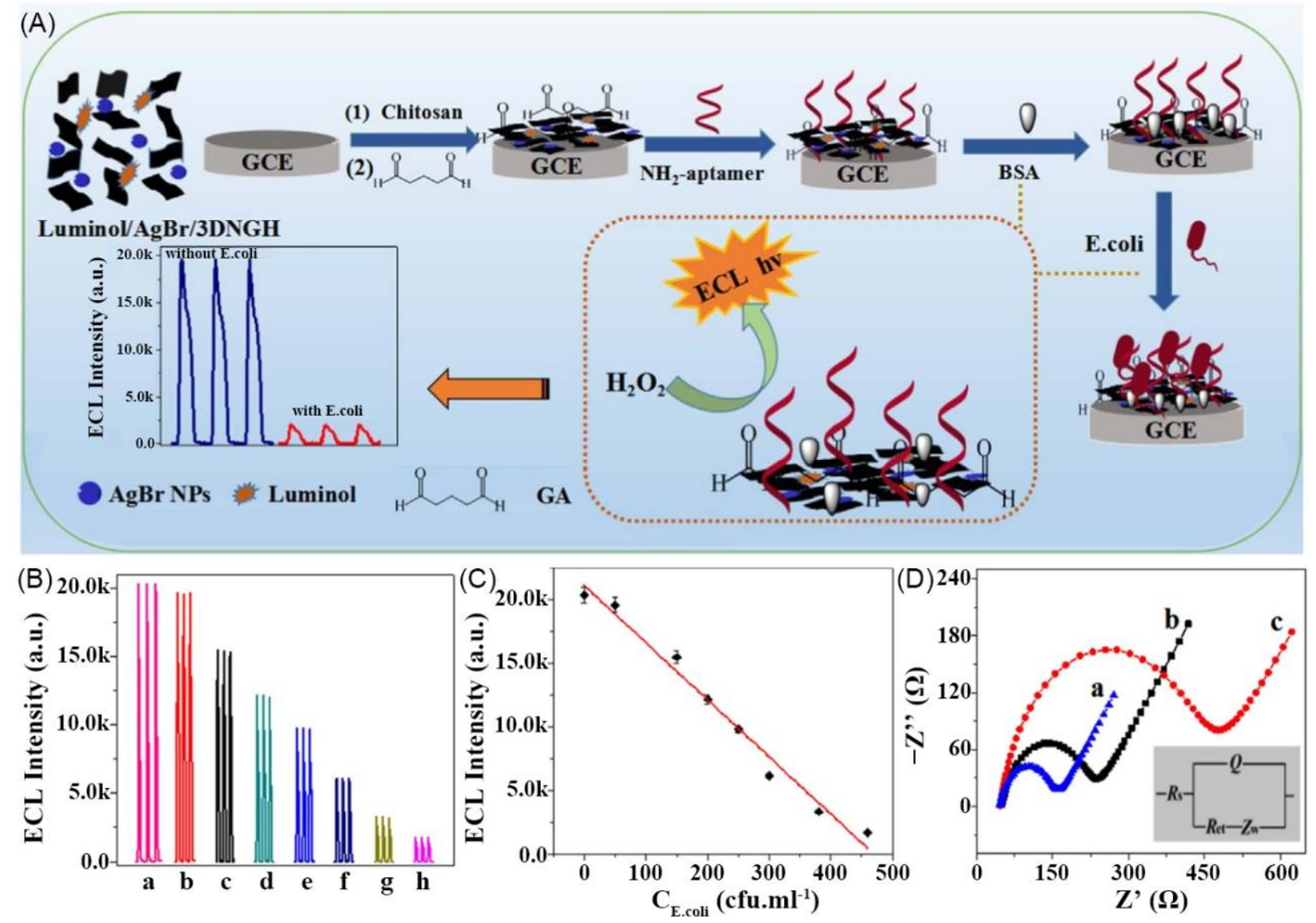

Figure 7. (A) Schematic of fabrication process of luminol/AgBr/3DNGH-based ECL E. coli biosensor. (B) ECL responses of BSA/aptamer/GA/CHIT/luminol/AgBr/3DNGH/GCE in 0.1 M PBS (pH 8) with different concentrations of E. coli. (C) Calibration curve for E. coli detection. (D) EIS of GA/CHIT/luminol/AgBr/3DNGH/GCE (a), BSA/aptamer/GA/CHIT/luminol/AgBr/3DNGH/GCE nanocomposites before (b) and after (c) E. coli reaction. Adapted with permission [94]; copyright 2017, Elsevier Ltd.

Chen et al. designed and fabricated a luminescent conductive La-cholate/PAAm double network (DN) hydrogel with $\mathrm{La}^{3+}$-cholate-based supramolecular network as the first network and chemically cross-linked polyacrylamide (PAAm) as the second network (Figure 8A). The hydrogel emits blue fluorescent light, and the emission intensity decreases as the stretched length increases (Figure $8 \mathrm{~B}$ ). The ionic conductivity of the gel is $0.3 \mathrm{~S} \cdot \mathrm{m}^{-1}$, and it decreases as the stretched length increases. The gel was used as a strain sensor to monitor human movements. The results showed that the DN hydrogel can detect the movement of fingers, wrists, and knees. When the finger attached by the gel was bent at different angles from 0 to $120^{\circ}$, the resistance ratio of the gel could be observed to increase and recover at different angles (Figure 8C,D). The gel could also show resistant signal changes under the cyclic wrist bending from $0^{\circ}$ to $45^{\circ}$ (Figure $8 \mathrm{E}$ ) and the knee bending $0^{\circ}$ to $90^{\circ}$ (Figure $8 \mathrm{G}$ ). In addition, La-cholate/PAAm DN hydrogel can also detect human breathing and speech. When the gel was applied to the abdomen, the gel sensor could clearly record the small changes in the abdomen during breathing (Figure 8I,J). At the same time, the gel sensor located in the throat can change the resistance according to the vibration of the throat when speaking (Figure 8K,L) [110]. 

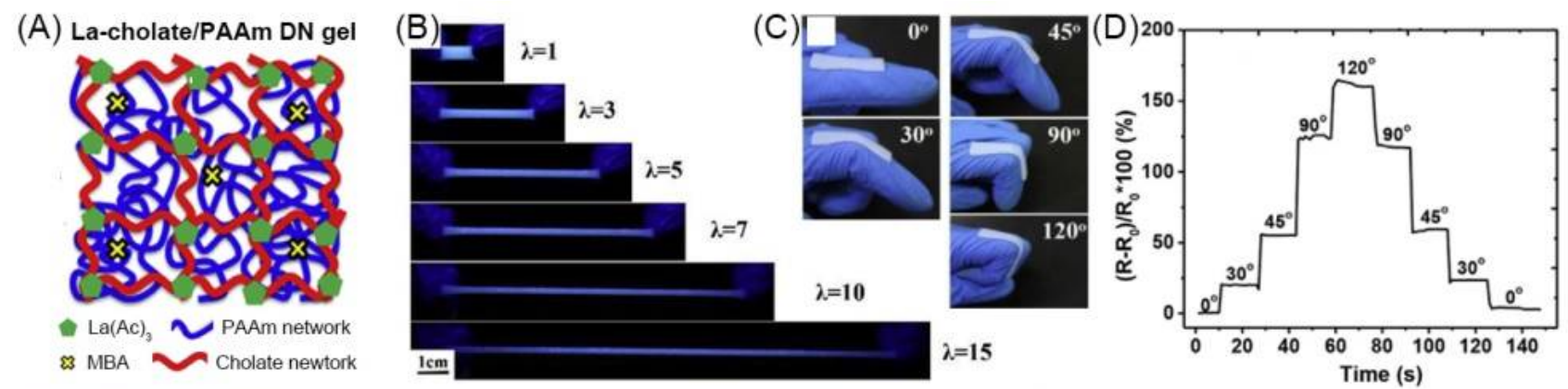
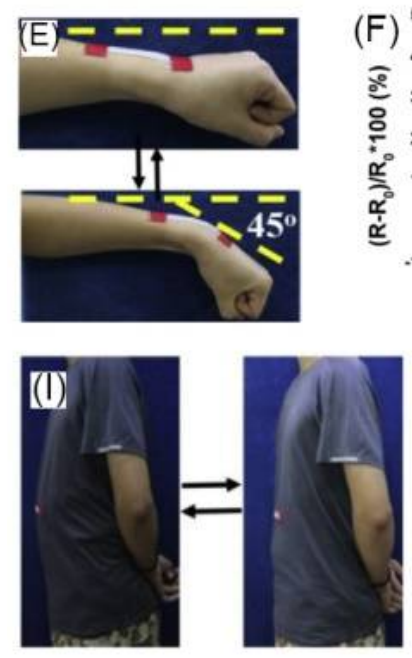
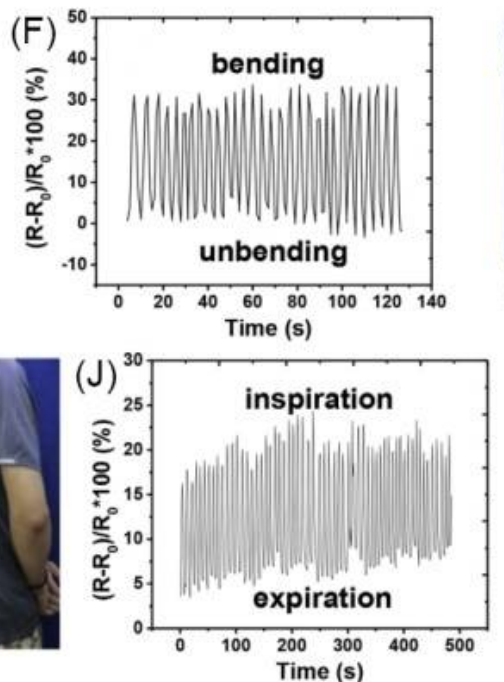
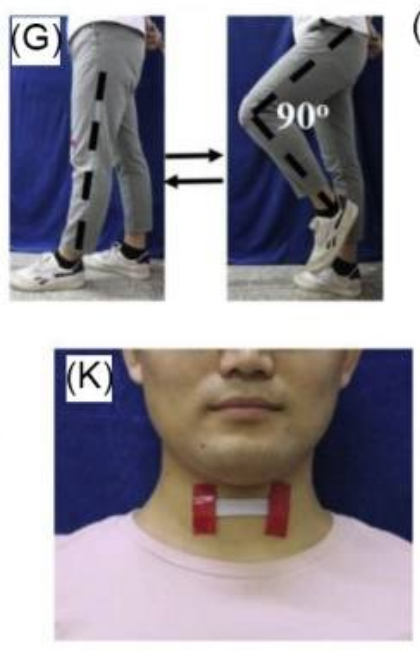
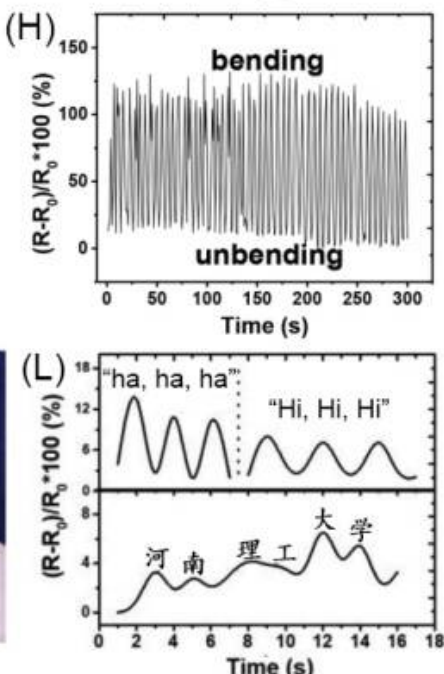

Figure 8. (A) Schematic of La-cholate/PAAm DN hydrogel network structure. (B) Fluorescent photographs of hydrogel under different strains. (C) Photographs show hydrogel adhered on a finger with different bending angles. (D) Change of resistance ratio of hydrogel with different bending angles. Photographs showing cyclic bending of wrist from 0 to $45^{\circ}$ (E) and relative resistance ratio change (F). Photographs showing cyclic bending of knee from 0 to $90^{\circ}$ (G) and relative resistance ratio change $(\mathbf{H})$. (I, J) Recording breathing during inspiration and expiration. $(\mathbf{K}, \mathbf{L})$ Detection of vibration of human throat during speaking. Adapted with permission [110]; copyright 2019, Elsevier Ltd.

Zhi et al. developed a multifunctional wearable smart skin device with touch-sensing, exteroception-visualizing, and energy-harvesting capabilities. The device consisted of three layers of dielectric elastomer (Ecoflex), conductive polyacrylic acid (PAA) hydrogel containing $\mathrm{NaCl}$, and Ecoflex-ZnS EL layer (Figure 9A). To study the function of smart skin, a 3 pixels $\times 3$ pixels sensor array was made with every constituted block of a size of $1 \times 1 \mathrm{~cm}$. The sensor array was attached to the hand, and when a single pixel was pressed in chronological order, the corresponding voltage signal output could be observed (Figure 9B,C). When a T-shaped acrylic plate was placed on the smart skin pixel, the force of the $\mathrm{T}$ position could be effectively detected (Figure 9D). The luminescence of the smart skin can respond to changes in force, and the luminous intensity has a nonlinear positive correlation with the applied force (Figure 9E). In addition, by randomly drawing various shapes on the smart skin, the real-time luminescence signal of the skin could be immediately visualized (Figure 9F). The smart skin can also collect mechanical energy, which can light up the LED circuit by tapping the smart skin with hand (Figure 9G). The mechanical energy of the smart skin can be converted into electrical energy for continuous output and can charge the electronic watch (Figure 9I). Figure 9H is the equivalent circuit of this process [27]. 

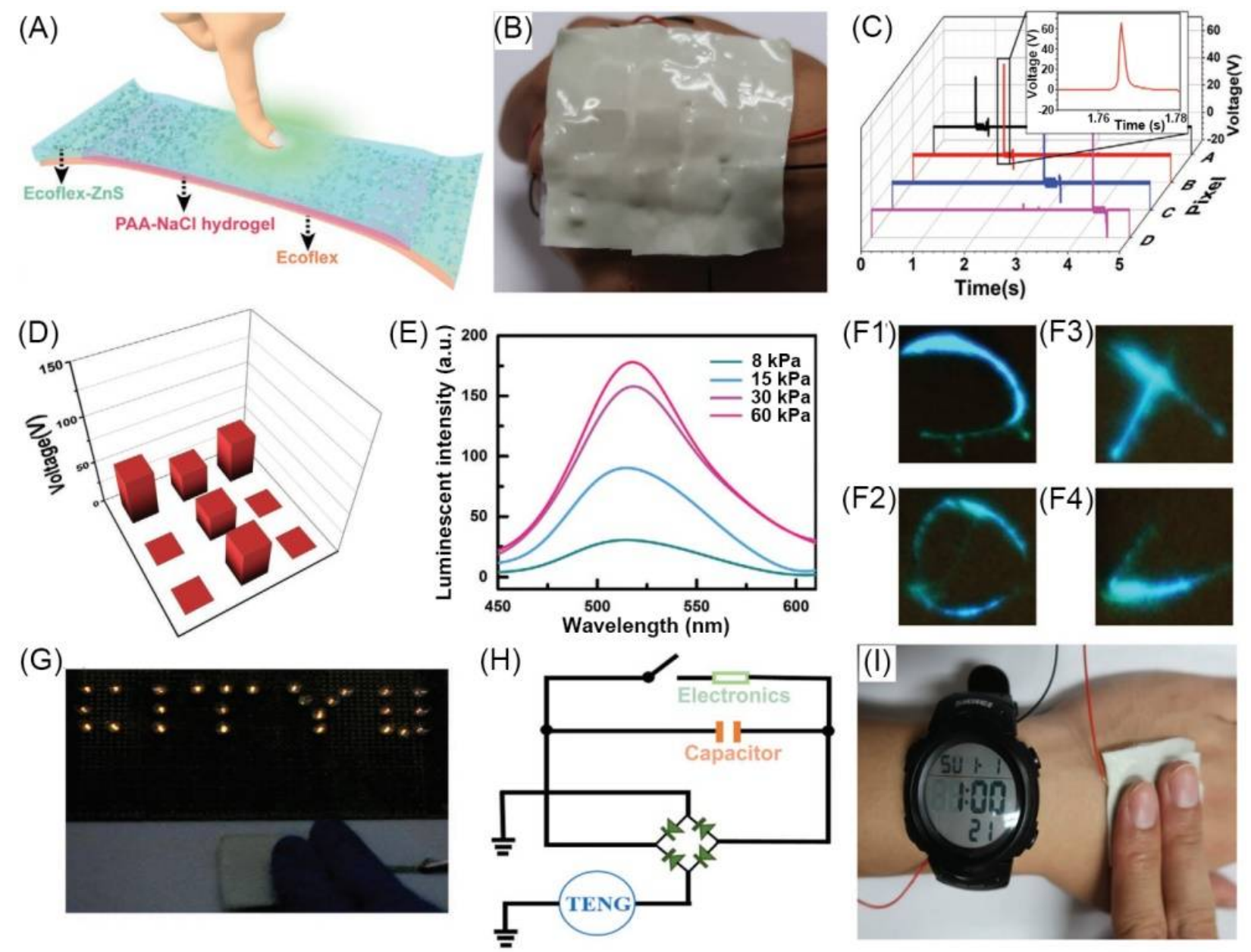

Figure 9. (A) Structural configuration of Ecoflex/hydrogel/Ecoflex gel composite-based smart skin device. (B) Photograph of the smart skin containing nine hydrogel pixels on back of a hand. (C) Electric signals at different pixels for detection of pressure location. (D) Voltage signals of nine pixels with a " $\mathrm{T}$ " shaped acrylic plate placed on skin. (E) Mechanoluminescent intensity of skin at various pressure magnitudes. (F1-4) Photographs of a real-time tracking of ML signals by external force. (G) Photograph of smart skin to power LEDs to demonstrate energy-harvesting property. (H) Equivalent circuit of a self-charging system to power an electronic watch (I). Adapted with permission [27]; copyright 2019, Wiley-VCH Verlag $\mathrm{GmbH} \&$ Co. KGaA, Weinheim.

\section{Conclusions and Perspectives}

The gel-based luminescent conductive material is a perfect combination of various properties such as adjustable mechanical strength, biocompatibility, luminescence, and conductivity. The synergistic collection of these properties means that gel-based luminescent conductive materials benefit from these properties in the application and have the advantage of synergistic properties. Compared with that of traditional rigid sensors and electronic devices, the flexibility, good mechanical properties, and biocompatibility of gelbased luminescent conductive materials enable them to be used in nonplanar and various complex biological environments. Moreover, gel-based luminescent conductive materials have the advantages of conductive functions in sensing and electronic devices, such as easy control, high accuracy, and mathematics of signals. Also, they have the advantages of high sensitivity and wide linear range in the detection of luminescence functions. Meanwhile, dual-signal detection and comparison make them more reliable and accurate than single-signal sensors and electronic devices. Diverse gel-based luminescent conductive materials were developed due to the diversity of choices on gels, luminescent materials, and conductive materials. With excellent optoelectronic features and biocompatibility, the 
gel-based luminescent conductive materials have shown great potential in applications in biosensors and bioelectronics.

Although gel-based luminescent conductive materials have many excellent characteristics, there are still many challenges to be faced. Firstly, excellent mechanical properties are significant to wearable bioelectronics. The mechanical properties of current luminescent conductive gels need to be improved. Their mechanical properties can be increased by using advanced high-strength gel structures such as double network and nanocomposite network. Secondly, the biocompatibility of the gel-based luminescent conductive materials needs to be comprehensively evaluated in clinical application. Thirdly, although gel-based luminescent conductive materials were developed and applied in biosensors and bioelectronics, their luminescent and electrical properties are generally used independently. Therefore, it is necessary to design the gel network structure reasonably and intelligently at the microscope level (molecular level or aggregation level) to realize the synergistic effect of the two properties and significantly improve the material properties. Finally, although gel-based luminescent conductive materials were applied in the fields of biosensors and bioelectronics, their application is still in its infancy, and further research and development are needed to enable commercial applications.

Overall, gel-based luminescent conductive materials are anticipated to serve as a powerful platform for development of advanced biosensors and bioelectronics. It is hoped that this review could inspire more interest in this emerging field. In addition, the illustration of the research approach about this interdisciplinary field is hoped to showcase the thought to exploit new interdisciplinary fields.

Author Contributions: Z.L. provided the conceptualization of the review and gave the supervision; J.Q. searched and compiled references involved in the review; J.Q. and Z.L. wrote the review; G.S. modified the review and polished the language. All authors have read and agreed to the published version of the manuscript.

Funding: The authors acknowledge funding from the National Natural Science Foundation of China (22005028), and Beijing Institute of Technology Research Fund Program for Young Scholars (XSQD-202023002).

Data Availability Statement: Data is contained within the article.

Conflicts of Interest: The authors declare no conflict of interest.

\section{References}

1. Fu, Z.; Lu, Y.-C.; Lai, J.J. Recent Advances in Biosensors for Nucleic Acid and Exosome Detection. Chonnam Med. J. 2019, 55, 86-98. [CrossRef]

2. Pohanka, M.; Skladal, P.; Kroea, M. Biosensors for biological warfare agent detection. Def. Sci. J. 2007, 57, 185-193. [CrossRef]

3. Gerard, M.; Chaubey, A.; Malhotra, B.D. Application of conducting polymers to biosensors. Biosens. Bioelectron. 2002, 17, 345-359. [CrossRef]

4. Yao, G.; Yin, C.; Wang, Q.; Zhang, T.; Chen, S.; Lu, C.; Zhao, K.; Xu, W.; Pan, T.; Gao, M.; et al. Flexible bioelectronics for physiological signals sensing and disease treatment. J. Mater. 2020, 6, 397-413. [CrossRef]

5. Parlak, O.; Turner, A.P.F. Switchable bioelectronics. Biosens. Bioelectron. 2016, 76, 251-265. [CrossRef]

6. Li, Y.; Li, N.; De Oliveira, N.; Wang, S. Implantable bioelectronics toward long-term stability and sustainability. Matter 2021, 4, 1125-1141. [CrossRef]

7. Zavanelli, N.; Kim, J.; Yeo, W.-H. Recent Advances in High-Throughput Nanomaterial Manufacturing for Hybrid Flexible Bioelectronics. Materials 2021, 14, 2973. [CrossRef]

8. Löffler, S.; Libberton, B.; Richter-Dahlfors, A. Organic Bioelectronic Tools for Biomedical Applications. Electronics 2015, 4, 879-908. [CrossRef]

9. Liao, C.Z.; Zhang, M.; Yao, M.Y.; Hua, T.; Li, L.; Yan, F. Flexible Organic Electronics in Biology: Materials and Devices. Adv. Mater. 2015, 27, 7493-7527. [CrossRef]

10. Liu, Y.X.; Feig, V.R.; Bao, Z.A. Conjugated Polymer for Implantable Electronics toward Clinical Application. Adv. Healthc. Mater. 2021, 10, 2001916. [CrossRef]

11. Fidanovski, K.; Mawad, D. Conjugated Polymers in Bioelectronics: Addressing the Interface Challenge. Adv. Healthc. Mater. 2019, 8, 1900053. [CrossRef] 
12. Cheng, Y.; Wang, K.; Xu, H.; Li, T.; Jin, Q.; Cui, D. Recent developments in sensors for wearable device applications. Anal. Bioanal. Chem. 2021, 413, 6037-6057. [CrossRef]

13. Mohankumar, P.; Ajayan, J.; Mohanraj, T.; Yasodharan, R. Recent developments in biosensors for healthcare and biomedical applications: A review. Measurement 2021, 167, 108293. [CrossRef]

14. Song, S.; Xu, H.; Fan, C.H. Potential diagnostic applications of biosensors: Current and future directions. Int. J. Nanomed. 2006, 1 , 433-440. [CrossRef]

15. Sunwoo, S.H.; Ha, K.H.; Lee, S.; Lu, N.; Kim, D.H. Wearable and Implantable Soft Bioelectronics: Device Designs and Material Strategies. Annu. Rev. Chem. Biomol. 2021, 12, 359-391. [CrossRef] [PubMed]

16. Tang, L.; Wu, S.J.; Qu, J.; Gong, L.; Tang, J.X. A Review of Conductive Hydrogel Used in Flexible Strain Sensor. Materials 2020, 13, 3947. [CrossRef] [PubMed]

17. Wang, L.R.; Xu, T.L.; Zhang, X.J. Multifunctional conductive hydrogel-based flexible wearable sensors. TrAC Trends Anal. Chem. 2021, 134, 116130. [CrossRef]

18. Fu, F.F.; Wang, J.L.; Zeng, H.B.; Yu, J. Functional Conductive Hydrogels for Bioelectronics. ACS Mater. Lett. 2020, 2, 1287-1301. [CrossRef]

19. Lei, K.; Li, Z.; Zhu, D.D.; Sun, C.Y.; Sun, Y.L.; Yang, C.C.; Zheng, Z.; Wang, X.L. Polysaccharide-based recoverable double-network hydrogel with high strength and self-healing properties. J. Mater. Chem. B 2020, 8, 794-802. [CrossRef] [PubMed]

20. Ji, X.F.; Li, Z.; Liu, X.L.; Peng, H.Q.; Song, F.Y.; Qi, J.; Lam, J.W.Y.; Long, L.L.; Sessler, J.L.; Tang, B.Z. A Functioning Macroscopic "Rubik's Cube" Assembled via Controllable Dynamic Covalent Interactions. Adv. Mater. 2019, 31, 1902365. [CrossRef]

21. Xiong, L.; Feng, J.; Hu, R.; Wang, S.Q.; Li, S.Y.; Li, Y.; Yang, G.Q. Sensing in $15 \mathrm{~s}$ for Aqueous Fluoride Anion by Water-Insoluble Fluorescent Probe Incorporating Hydrogel. Anal. Chem. 2013, 85, 4113-4119. [CrossRef]

22. An, R.; Zhang, X.Y.; Han, L.L.; Wang, X.D.; Zhang, Y.L.; Shi, L.Y.; Ran, R. Healing, flexible, high thermal sensitive dual-network ionic conductive hydrogels for 3D linear temperature sensor. Mater. Sci. Eng. C Mater. Biol. Appl. 2020, 107, 110310. [CrossRef]

23. Shi, Y.; Zhang, J.; Pan, L.J.; Shi, Y.; Yu, G.H. Energy gels: A bio-inspired material platform for advanced energy applications. Nano Today 2016, 11, 738-762. [CrossRef]

24. Kageyama, R.; Kagami, S.; Inaba, M.; Inoue, H. A soft tactile sensor made of conductive-gel and its applications. Adv. Robot. 1999, 13, 301-302. [CrossRef]

25. Li, Z.; Liu, P.C.; Ji, X.F.; Gong, J.Y.; Hu, Y.B.; Wu, W.J.; Wang, X.N.; Peng, H.Q.; Kwok, R.T.K.; Lam, J.W.Y.; et al. Bioinspired Simultaneous Changes in Fluorescence Color, Brightness, and Shape of Hydrogels Enabled by AIEgens. Adv. Mater. 2020, 32, 1906493. [CrossRef]

26. Xu, L.H.; Li, J.J.; Zeng, H.B.; Zhang, X.J.; Cosnier, S.; Marks, R.S.; Shan, D. ATMP-induced three-dimensional conductive polymer hydrogel scaffold for a novel enhanced solid-state electrochemiluminescence biosensor. Biosens. Bioelectron. 2019, $143,111601$. [CrossRef]

27. Liang, G.J.; Ruan, Z.H.; Liu, Z.X.; Li, H.F.; Wang, Z.F.; Tang, Z.J.; Mo, F.N.; Yang, Q.; Ma, L.T.; Wang, D.H.; et al. Toward Multifunctional and Wearable Smart Skins with Energy-Harvesting, Touch-Sensing, and Exteroception-Visualizing Capabilities by an All-Polymer Design. Adv. Electron. Mater. 2019, 5, 1900553. [CrossRef]

28. Zhang, Y.S.; Khademhosseini, A. Advances in engineering hydrogels. Science 2017, 356, eaaf3627. [CrossRef] [PubMed]

29. Witzmann, F.A.; Bai, F.J.; Hong, S.M.; Liu, S.; Pedrick, N.; Ringham, H.; Tan, J. Gels and more gels: Probing toxicity. Curr. Opin. Mol. Ther. 2004, 6, 608-615. [PubMed]

30. Clark, A.H. Biopolymer gels. Curr. Opin. Colloid Interface Sci. 1996, 1, 712-717. [CrossRef]

31. Scherer, G.W. Drying gels. 5. Rigid gels. J. Non-Cryst. Solids 1987, 92, 122-144.

32. Flory, P.J. Gels and gelling processes-Introduction. Faraday Discuss. 1975, 57, 7-18. [CrossRef]

33. Li, Z.; Su, S.; Yu, L.; Zheng, Z.; Wang, X.L. Preparation of a photo- and thermo-responsive topological gel from anthracenemodified polyrotaxanes. Soft Matter 2018, 14, 2767-2771. [CrossRef] [PubMed]

34. Teale, F.W.J. Exciting stuff. Nature 1984, 307, 486. [CrossRef]

35. Thomas, D.G. Electroluminescence. Phys. Today 1968, 21, 43. [CrossRef]

36. Richter, M.M. Electrochemiluminescence (ECL). Chem. Rev. 2004, 104, 3003-3036. [CrossRef]

37. Hastings, J.W.; Johnson, C.H. [3] Bioluminescence and chemiluminescence. In Methods Enzymology; Marriott, G., Parker, I., Eds.; Elsvier Inc.: Amsterdam, The Netherlands, 2003; Volume 360, pp. 75-104.

38. Rossello, J.M.; Dellavale, D.; Bonetto, F.J. Stable tridimensional bubble clusters in multi-bubble sonoluminescence (MBSL). Ultrason. Sonochemistry 2015, 22, 59-69. [CrossRef]

39. Zhao, Q.; Yang, Q. Transforming the behavior of conventional chromophores from aggregation-caused quenching to aggregationinduced emission. J. Funct. Mater. 2015, 46, 14001-14011.

40. Cai, X.L.; Liu, B. Aggregation-Induced Emission: Recent Advances in Materials and Biomedical Applications. Angew. Chem. Int. Ed. 2020, 59, 9868-9886. [CrossRef]

41. Omote, Y.; Miyake, T.; Ohmori, S.; Sugiyama, N. Chemiluminescence of luminol and acetyl-luminol. Bull. Chem. Soc. Jpn. 1967, 40, 899-903. [CrossRef]

42. Zheng, X.W.; Guo, Z.H.; Zhang, Z.J. Flow-injection electrogenerated chemiluminescence determination of epinephrine using luminol. Anal. Chim. Acta 2001, 441, 81-86. [CrossRef]

43. Hall, C.; Perutz, R.N. Transition metal alkane complexes. Chem. Rev. 1996, 96, 3125-3146. [CrossRef] 
44. Zhao, Q.; Huang, C.H.; Li, F.Y. Phosphorescent heavy-metal complexes for bioimaging. Chem. Soc. Rev. 2011, 40, $2508-2524$. [CrossRef]

45. Ma, D.L.; He, H.Z.; Leung, K.H.; Chan, D.S.H.; Leung, C.H. Bioactive Luminescent Transition-Metal Complexes for Biomedical Applications. Angew. Chem. Int. Ed. 2013, 52, 7666-7682. [CrossRef] [PubMed]

46. Song, Y.H.; Chiu, Y.C.; Chi, Y.; Cheng, Y.M.; Lai, C.H.; Chou, P.T.; Wong, K.T.; Tsai, M.H.; Wu, C.C. Phosphorescent iridium(III) complexes with nonconjugated cyclometalated ligands. Chem. A Eur. J. 2008, 14, 5423-5434. [CrossRef]

47. Borgstrom, M.; Ott, S.; Lomoth, R.; Bergquist, J.; Hammarstrom, L.; Johansson, O. Photoinduced energy transfer coupled to charge separation in a Ru(II)-Ru(II)-acceptor triad. Inorg. Chem. 2006, 45, 4820-4829. [CrossRef]

48. Kumar, P.; Soumya, S.; Prasad, E. Enhanced Resonance Energy Transfer and White-Light Emission from Organic Fluorophores and Lanthanides in Dendron-based Hybrid Hydrogel. ACS Appl. Mater. Interfaces 2016, 8, 8068-8075. [CrossRef] [PubMed]

49. Bekiari, V.; Thiakou, K.A.; Raptopoulou, C.P.; Perlepes, S.P.; Lianos, P. Structure and photophysical behavior of 2,2' bipyrimidine/lanthanide ion complexes in various environments. J. Lumin. 2008, 128, 481-488. [CrossRef]

50. Petryayeva, E.; Algar, W.R.; Medintz, I.L. Quantum Dots in Bioanalysis: A Review of Applications Across Various Platforms for Fluorescence Spectroscopy and Imaging. Appl. Spectrosc. 2013, 67, 215-252. [CrossRef]

51. Coe-Sullivan, S.; Liu, W.H.; Allen, P.; Steckel, J.S. Quantum Dots for LED Downconversion in Display Applications. ECS J. Solid State Sci. Technol. 2013, 2, R3026-R3030. [CrossRef]

52. Fang, Y.X.; Guo, S.J.; Li, D.; Zhu, C.Z.; Ren, W.; Dong, S.J.; Wang, E.K. Easy Synthesis and Imaging Applications of Cross-Linked Green Fluorescent Hollow Carbon Nanoparticles. ACS Nano 2012, 6, 400-409. [CrossRef] [PubMed]

53. Baker, S.N.; Baker, G.A. Luminescent Carbon Nanodots: Emergent Nanolights. Angew. Chem. Int. Ed. 2010, 49, 6726-6744. [CrossRef] [PubMed]

54. Campelo, J.M.; Luna, D.; Luque, R.; Marinas, J.M.; Romero, A.A. Sustainable Preparation of Supported Metal Nanoparticles and Their Applications in Catalysis. ChemSusChem 2009, 2, 18-45. [CrossRef] [PubMed]

55. Gangopadhyay, S.; Hadjipanayis, G.C.; Sorensen, C.M.; Klabunde, K.J. Effect of particle-size and surface-chemistry on the interactions among fine metallic particles. IEEE Trans. Magn. 1993, 29, 2619-2621. [CrossRef]

56. Orbach, R.; Guo, W.W.; Wang, F.; Lioubashevski, O.; Willner, I. Self-Assembly of Luminescent Ag Nanocluster-Functionalized Nanowires. Langmuir 2013, 29, 13066-13071. [CrossRef] [PubMed]

57. Guo, W.W.; Yuan, J.P.; Dong, Q.Z.; Wang, E.K. Highly Sequence-Dependent Formation of Fluorescent Silver Nanoclusters in Hybridized DNA Duplexes for Single Nucleotide Mutation Identification. J. Am. Chem. Soc. 2010, 132, 932-934. [CrossRef]

58. Jin, R.C. Atomically precise metal nanoclusters: Stable sizes and optical properties. Nanoscale 2015, 7, 1549-1565. [CrossRef]

59. Yang, S.; Wang, Y.; Liu, P.R.; Cheng, Y.B.; Zhao, H.J.; Yang, H.G. Functionalization of perovskite thin films with moisture-tolerant molecules. Nat. Energy 2016, 1, 15016. [CrossRef]

60. Liu, Z.; Wu, Q.; Zhong, F. Progress in Research of Inorganic-Organic Hybrid Materials. Petrochem. Technol. 2008, $37,649-655$.

61. Zhu, Y.C.; Bando, Y.; Uemura, Y. ZnS-Zn nanocables and ZnS nanotubes. Chem. Commun. 2003, 836-837. [CrossRef]

62. Borodina, T.A.; Minakova, T.S. Quantum yield of oxygen photoadsorption on ZNS, ZNS-CU and ZNS-AG. Zhurnal Fiz. Khimii 1978, 52, 1203-1205.

63. Han, H. Preparation of fast ionic conductors and its application. New Chem. Mater. 2003, 31, $22-25$.

64. Keplinger, C.; Sun, J.Y.; Foo, C.C.; Rothemund, P.; Whitesides, G.M.; Suo, Z.G. Stretchable, Transparent, Ionic Conductors. Science 2013, 341, 984-987. [CrossRef] [PubMed]

65. Zhang, Q.; Wang, R.; Li, Z.; Deng, Y. Advances of Ionic Liquid Application in Green Catalysis and Clean Synthesis. Petrochem. Technol. 2007, 36, 975-984.

66. Qian, J.; Li, X.; Luan, H.; Li, H.; Li, P. Electrochemical Properties of Ionic Liquids and Solubility of IrCl_3. Chin. J. Rare Met. 2015, 39, 136-143.

67. Kausar, A. Research Progress in Frontiers of Poly(Ionic Liquid)s: A Review. Polym.-Plast. Technol. Eng. 2017, 56, 1823-1838. [CrossRef]

68. Ge, X.; Gu, C.D.; Wang, X.L.; Tu, J.P. Deep eutectic solvents (DESs)-derived advanced functional materials for energy and environmental applications: Challenges, opportunities, and future vision. J. Mater. Chem. A 2017, 5, 8209-8229. [CrossRef]

69. Hu, P.; Jiang, W.; Zhong, L. Study on properties of deep eutectic solvents and their applications. Mod. Chem. Ind. 2018, 38, 53-57.

70. Feng, X.D.; Kawabata, K.; Cowan, M.G.; Dwulet, G.E.; Toth, K.; Sixdenier, L.; Haji-Akbari, A.; Noble, R.D.; Elimelech, M.; Gin, D.L.; et al. Single crystal texture by directed molecular self-assembly along dual axes. Nat. Mater. 2019, 18, 1235-1243. [CrossRef]

71. Kumar, S. Self-organization of disc-like molecules: Chemical aspects. Chem. Soc. Rev. 2006, 35, 83-109. [CrossRef]

72. Hirst, A.R.; Escuder, B.; Miravet, J.F.; Smith, D.K. High-Tech Applications of Self-Assembling Supramolecular Nanostructured Gel-Phase Materials: From Regenerative Medicine to Electronic Devices. Angew. Chem. Int. Ed. 2008, 47, 8002-8018. [CrossRef] [PubMed]

73. Szollosi, A.; Hoschke, A.; Rezessy-Szabo, J.M.; Bujna, E.; Kun, S.; Nguyen, Q.D. Formation of novel hydrogel bio-anode by immobilization of biocatalyst in alginate/polyaniline/titanium-dioxide/graphite composites and its electrical performance. Chemosphere 2017, 174, 58-65. [CrossRef] [PubMed]

74. Min, J.H.; Patel, M.; Koh, W.G. Incorporation of Conductive Materials into Hydrogels for Tissue Engineering Applications. Polymers 2018, 10, 1078. [CrossRef] [PubMed] 
75. Lee, G.H.; Cooper, R.C.; An, S.J.; Lee, S.; van der Zande, A.; Petrone, N.; Hammerherg, A.G.; Lee, C.; Crawford, B.; Oliver, W.; et al. High-Strength Chemical-Vapor Deposited Graphene and Grain Boundaries. Science 2013, 340, 1073-1076. [CrossRef]

76. Xu, Y.X.; Sheng, K.X.; Li, C.; Shi, G.Q. Self-Assembled Graphene Hydrogel via a One-Step Hydrothermal Process. ACS Nano 2010, 4, 4324-4330. [CrossRef] [PubMed]

77. Qian, X.; Li, H.; Ding, L.; Wu, C. Research progress of a new organic conductive and luminescent material poly(3,4ethylenedioxythiophene) (PEDOT). New Chem. Mater. 2005, 33, 17-20.

78. Masi, J.V. New developments in polymers: Conductive and active (magnetic, luminescent and electronic) applications. In Proceedings of the Electrical Insulation Conference and Electrical Manufacturing Expo, Indianapolis, IN, USA, 23-26 October 2005; pp. 299-306.

79. Zhou, Y.; Wan, C.J.; Yang, Y.S.; Yang, H.; Wang, S.C.; Dai, Z.D.; Ji, K.J.; Jiang, H.; Chen, X.D.; Long, Y. Highly Stretchable, Elastic, and Ionic Conductive Hydrogel for Artificial Soft Electronics. Adv. Funct. Mater. 2019, 29, 1806220. [CrossRef]

80. Wei, S.X.; Li, Z.; Lu, W.; Liu, H.; Zhang, J.W.; Chen, T.; Tang, B.Z. Multicolor Fluorescent Polymeric Hydrogels. Angew. Chem. Int. Ed. 2021, 60, 8608-8624. [CrossRef]

81. Garcia, F.; Buendia, J.; Ghosh, S.; Ajayaghosh, A.; Sanchez, L. Luminescent and conductive supramolecular polymers obtained from an N-annulated perylenedicarboxamide. Chem. Commun. 2013, 49, 9278-9280. [CrossRef]

82. Pandey, V.K.; Dixit, M.K.; Manneville, S.; Bucher, C.; Dubey, M. A multi-stimuli responsive conductive sonometallogel: A mechanistic insight into the role of ultrasound in gelation. J. Mater. Chem. A 2017, 5, 6211-6218. [CrossRef]

83. Liu, G.; Ma, C.; Jin, B.K.; Chen, Z.X.; Cheng, F.L.; Zhu, J.J. Electrochemiluminescence Investigation of Glucose Transporter 4 Expression at Skeletal Muscle Cells Surface Based on a Graphene Hydrogel Electrode. Anal. Chem. 2019, 91, 3021-3026. [CrossRef]

84. Mohanan, V.V.; Pradhan, B.; Sridurai, V.; Yelamaggad, C.V.; Achalkumar, A.S.; Nair, G.G. Giant enhancement and facile tuning of photoluminescence in a soft anisotropic magneto-gel. Nanoscale 2018, 10, 15686-15695. [CrossRef]

85. Tong, X.; Zhao, Y.; An, B.K.; Park, S.Y. Fluorescent liquid-crystal gels with electrically switchable photoluminescence. Adv. Funct. Mater. 2006, 16, 1799-1804. [CrossRef]

86. Tong, X.; Chung, J.W.; Park, S.Y.; Zhao, Y. Self-Assembled Liquid-Crystal Gels in an Emulsion. Langmuir 2009, $25,8532-8537$. [CrossRef] [PubMed]

87. Samanta, S.K.; Bhattacharya, S. Aggregation induced emission switching and electrical properties of chain length dependent pi-gels derived from phenylenedivinylene bis-pyridinium salts in alcohol-water mixtures. J. Mater. Chem. 2012, 22, 25277-25287. [CrossRef]

88. De, J.; Devi, M.; Shah, A.; Gupta, S.P.; Bala, I.; Singh, D.P.; Douali, R.; Pal, S.K. Luminescent Conductive Columnar pi-Gelators for Fe(II) Sensing and Bio-Imaging Applications. J. Phys. Chem. B 2020, 124, 10257-10265. [CrossRef]

89. Xue, P.C.; Lu, R.; Zhao, L.; Xu, D.F.; Zhang, X.F.; Li, K.C.; Song, Z.G.; Yang, X.C.; Takafuji, M.; Thara, H. Hybrid Self-Assembly of a pi Gelator and Fullerene Derivative with Photoinduced Electron Transfer for Photocurrent Generation. Langmuir 2010, 26, 6669-6675. [CrossRef]

90. Dixit, M.K.; Chery, D.; Mahendar, C.; Bucher, C.; Dubey, M. Nanofabrication of Au nanoparticles over conductive metallohydrogel nanofibers for nanocatalysis application. Inorg. Chem. Front. 2020, 7, 991-1002. [CrossRef]

91. Shukla, J.; Kumar, Y.; Dixit, M.K.; Mahendar, C.; Sharma, V.K.; Kalam, A.; Dubey, M. Investigation of the Mechanism Behind Conductive Fluorescent and Multistimuli-responsive $\mathrm{Li}^{+}$-enriched Metallogel Formation. Chem. Asian J. 2020, 15, 3020-3028. [CrossRef]

92. Mahendar, C.; Kumar, Y.; Dixit, M.K.; Mukherjee, M.; Kalam, A.; Dubey, M. Conductive Zn(ii)-metallohydrogels: The role of alkali metal cation size in gelation, rheology and conductance. Mol. Syst. Des. Eng. 2021, 6, 654-661. [CrossRef]

93. Le, N.H.; Seema, H.; Kemp, K.C.; Ahmed, N.; Tiwari, J.N.; Park, S.; Kim, K.S. Solution-processable conductive micro-hydrogels of nanoparticle/graphene platelets produced by reversible self-assembly and aqueous exfoliation. J. Mater. Chem. A 2013, 1, 12900-12908. [CrossRef]

94. Hao, N.; Zhang, X.; Zhou, Z.; Hua, R.; Zhang, Y.; Liu, Q.; Qian, J.; Li, H.; Wang, K. AgBr nanoparticles/3D nitrogen-doped graphene hydrogel for fabricating all-solid-state luminol-electrochemiluminescence Escherichia coli aptasensors. Biosens. Bioelectron. 2017, 97, 377-383. [CrossRef] [PubMed]

95. Jiang, X.Y.; Wang, H.J.; Yuan, R.; Chai, Y.Q. Functional Three-Dimensional Porous Conductive Polymer Hydrogels for Sensitive Electrochemiluminescence In Situ Detection of $\mathrm{H}_{2} \mathrm{O}_{2}$ Released from Live Cells. Anal. Chem. 2018, 90, 8462-8469. [CrossRef]

96. Ding, C.F.; Li, Y.X.; Wang, L.; Luo, X.L. Ratiometric Electrogenerated Chemiluminescence Cytosensor Based on Conducting Polymer Hydrogel Loaded with Internal Standard Molecules. Anal. Chem. 2019, 91, 983-989. [CrossRef]

97. Han, C.Y.; Guo, W.W. Fluorescent Noble Metal Nanoclusters Loaded Protein Hydrogel Exhibiting Anti-Biofouling and SelfHealing Properties for Electrochemiluminescence Biosensing Applications. Small 2020, 16, 2002621. [CrossRef] [PubMed]

98. Jiang, H.; Qin, Z.J.; Zheng, Y.K.; Liu, L.; Wang, X.M. Aggregation-Induced Electrochemiluminescence by Metal-Binding Protein Responsive Hydrogel Scaffolds. Small 2019, 15, 1901170. [CrossRef]

99. Li, Y.; He, L.; Huang, C.Z.; Li, Y.F. Silver-based metal-organic gels as novel coreactant for enhancing electrochemiluminescence and its biosensing potential. Biosens. Bioelectron. 2019, 134, 29-35. [CrossRef]

100. Zhang, Y.W.; Liu, W.S.; Chen, J.S.; Niu, H.L.; Mao, C.J.; Jin, B.K. Metal-organic gel and metal-organic framework based switchable electrochemiluminescence RNA sensing platform for Zika virus. Sens. Actuators B Chem. 2020, 321, 128456. [CrossRef] 
101. Cui, L.; Zhao, M.H.; Li, C.C.; Wang, Q.B.; Luo, X.L.; Zhang, C.Y. A Host-Guest Interaction-Based and Metal-Organic Gel-Based Biosensor with Aggregation-Induced Electrochemiluminescence Enhancement for Methyltransferase Assay. Anal. Chem. 2021, 93, 2974-2981. [CrossRef]

102. Wang, C.; Han, Q.; Liu, P.K.; Zhang, G.; Song, L.; Zou, X.C.; Fu, Y.Z. A Superstable Luminescent Lanthanide Metal Organic Gel Utilized in an Electrochemiluminescence Sensor for Epinephrine Detection with a Narrow Potential Sweep Range. ACS Sens. 2021, 6, 252-258. [CrossRef]

103. Zhang, X.; Nie, Y.X.; Zhang, Q.; Liang, Z.H.; Wang, P.L.; Ma, Q. Polydopamine nanoparticles@MoS2 nanosheet aerogel-based ECL sensing system for MiRNA-126 detection. Chem. Eng. J. 2021, 411, 128428. [CrossRef]

104. Kwon, J.H.; Kim, Y.M.; Moon, H.C. Porous Ion Gel: A Versatile Ionotronic Sensory Platform for High-Performance, Wearable Ionoskins with Electrical and Optical Dual Output. ACS Nano 2021, 15, 15132-15141. [CrossRef] [PubMed]

105. Moon, H.C.; Lodge, T.P.; Frisbie, C.D. Electrochemiluminescent displays based on ion gels: Correlation between device performance and choice of electrolyte. J. Mater. Chem. C 2016, 4, 8448-8453. [CrossRef]

106. Berestetsky, N.; Vaganova, E.; Wachtel, E.; Leitus, G.; Goldberg, A.; Yitzchaik, S. Photoactive proton conductor: Poly(4-vinyl pyridine) gel. J. Phys. Chem. B 2008, 112, 3662-3667. [CrossRef] [PubMed]

107. Wang, G.C.; Zhao, J.; Li, X.W.; Li, C.Z.; Yuan, W.K. Synthesis and characterization of electrically conductive and fluorescent poly(N-5-(8-hydroxyquinoline)methyl aniline)/ $\mathrm{V}_{2} \mathrm{O}_{5}$ xerogel hybrids. Synth. Met. 2009, 159, 366-371. [CrossRef]

108. Xie, Z.L.; Xu, H.B.; Gessner, A.; Kumke, M.U.; Priebe, M.; Fromm, K.M.; Taubert, A. A transparent, flexible, ion conductive, and luminescent PMMA ionogel based on a Pt/Eu bimetallic complex and the ionic liquid Bmim N(Tf)(2). J. Mater. Chem. 2012, 22, 8110-8116. [CrossRef]

109. Gokceoren, A.T.; Alveroglu, E. Synthesis and investigation of poly(N-isopropylacrylamide-co-N-vinylcarbazole) hydrogels morphological, fluorescence and electrical properties. J. Mol. Struct. 2016, 1108, 25-32. [CrossRef]

110. Chen, F.; Tang, Z.Q.; Lu, S.P.; Zhu, L.; Wang, Q.L.; Gang, Q.; Yang, J.; Chen, Q. Fabrication and mechanical behaviors of novel supramolecular/polymer hybrid double network hydrogels. Polymer 2019, 168, 159-167. [CrossRef]

111. Liu, H.T.; Huang, C.L.; Liou, G.S. Design, Synthesis, and Electrofluorochromism of New Triphenylamine Derivatives with AIE-Active Pendent Groups. ACS Appl. Mater. Interfaces 2019, 11, 11684-11690. [CrossRef]

112. Cho, K.G.; Lee, J.I.; Lee, S.J.; Hong, K.Y.; Kang, M.S.; Lee, K.H. Light-Emitting Devices Based on Electrochemiluminescence Gels. Adv. Funct. Mater. 2020, 30, 1907936. [CrossRef]

113. Nobeshima, T.; Nakamura, K.; Kobayashi, N. Electrochemical Materials for Novel Light Emitting Device and Dual Mode Display. J. Photopolym. Sci. Technol. 2013, 26, 397-402. [CrossRef]

114. Liu, Z.Y.; Qi, W.J.; Xu, G.B. Recent advances in electrochemiluminescence. Chem. Soc. Rev. 2015, 44, 3117-3142. [CrossRef]

115. Daimon, T.; Nihei, E. Fabrication of organic electrochemiluminescence devices with pi-conjugated polymer materials. J. Mater. Chem. C 2013, 1, 2826-2833. [CrossRef]

116. Park, J.M.; Park, J.; Kim, Y.H.; Zhou, H.; Lee, Y.; Jo, S.H.; Ma, J.; Lee, T.W.; Sun, J.Y. Aromatic nonpolar organogels for efficient and stable perovskite green emitters. Nat. Commun. 2020, 11, 4638. [CrossRef] [PubMed]

117. Liang, G.J.; Liu, Z.X.; Mo, F.N.; Tang, Z.J.; Li, H.F.; Wang, Z.F.; Sarangi, V.; Pramanick, A.; Fan, J.; Zhi, C.Y. Self-healable electroluminescent devices. Light Sci. Appl. 2018, 7, 102. [CrossRef] [PubMed]

118. Yang, B.W.; Yuan, W. Highly Stretchable and Transparent Double-Network Hydrogel Ionic Conductors as Flexible ThermalMechanical Dual Sensors and Electroluminescent Devices. ACS Appl. Mater. Interfaces 2019, 11, 16765-16775. [CrossRef]

119. Yin, T.H.; Wu, L.; Wu, T.H.; Mao, G.Y.; Nian, G.D.; Chen, Z.; Hu, X.C.; Wang, P.; Xiang, Y.H.; Yu, H.H.; et al. Ultrastretchable and conductive core/sheath hydrogel fibers with multifunctionality. J. Polym. Sci. Part B Polym. Phys. 2019, 57, 272-280. [CrossRef]

120. Kwon, D.K.; Myoung, J.M. Wearable and Semitransparent Pressure-Sensitive Light-Emitting Sensor Based on Electrochemiluminescence. ACS Nano 2020, 14, 8716-8723. [CrossRef]

121. Kimura, M.; Miki, N.; Suzuki, D.; Adachi, N.; Tatewaki, Y.; Shirai, H. Wrapping of Self-Organized Fluorescent Nanofibers with a Silica Wall. Langmuir 2009, 25, 776-780. [CrossRef] 